\title{
CEsifo \\ WORKING

\section{The Falling Elasticity of Global Trade to Economic Activity: Testing the Demand Channel}

Marc Auboin, Floriana Borino 


\section{Impressum:}

CESifo Working Papers

ISSN 2364-1428 (electronic version)

Publisher and distributor: Munich Society for the Promotion of Economic Research - CESifo $\mathrm{GmbH}$

The international platform of Ludwigs-Maximilians University's Center for Economic Studies and the ifo Institute

Poschingerstr. 5, 81679 Munich, Germany

Telephone +49 (o)89 2180-2740, Telefax +49 (o)89 2180-17845, email office@cesifo.de

Editors: Clemens Fuest, Oliver Falck, Jasmin Gröschl

www.cesifo-group.org/wp

An electronic version of the paper may be downloaded

- from the SSRN website: $\quad$ www.SSRN.com

- from the RePEc website: $\quad$ www.RePEc.org

- from the CESifo website: www.CESifo-group.org/wp 


\title{
The Falling Elasticity of Global Trade to Economic Activity: Testing the Demand Channel
}

\begin{abstract}
Since the recovery from the great financial crisis in 2010, global real trade flows grew much slower than pre-crisis, in both absolute terms (growth rates) and relative terms (relative to GDP, from 2:1 in the great 1990's to 1:1 since 2012) A debate has arisen as to whether this global trade slowdown, and related falling trade-to-income elasticity, was structural or cyclical. Some papers emphasized the slowing pace of international vertical specialization. Other works emphasized the prominent role of aggregate demand, notably when weighted by its trade component. Our paper goes in this latter direction. We estimated the standard import equation for 38 advanced and developing countries over the period 1995-2015, using an import intensityadjusted measure of aggregate demand (IAD), calculated from input-output tables at country level, and compared results with regressions using GDP. The integration of IAD allows us to predict $76 \%$ to $86 \%$ of the changes in global imports, a better performance than if using GDP. The use of IAD also enabled us to measure the relative importance of each component of demand, according to their trade intensity. The model is able to account for over $90 \%$ of the recent trade slowdown (2012-2015), with IAD alone explaining $80 \%$ of it. The slowdown in global value chains explains more than half of the remaining share of the global trade slowdown, not explained by demand factors. Protectionism does not come up as statistically significant.
\end{abstract}

JEL-Codes: E220, F010, F130, F170, F440.

Keywords: investment, global outlook, trade policy, trade forecasting, business cycles.

Marc Auboin

Economic Research and Statistics Division World Trade Organization

Rue de Lausanne 154

Switzerland - 1211 Geneva 21

marc.auboin@wto.org
Floriana Borino

University of Genova / Switzerland

floriana.borino@gmail.com

Manuscript date: April 2017

This is a working paper, and hence it represents research in progress. The opinions expressed in this paper are those of its author. They are not intended to represent the positions or opinions of the WTO or its members and are without prejudice to members' rights and obligations under the WTO. Any errors are attributable to the author. 


\section{INTRODUCTION}

Since 2011, the real rate of growth of trade has been hovering around that of the global growth of GDP - in a 1:1 relationship (a little less than 3\% annually on average). The sluggish growth of trade contrasts with the pre-crisis period, when the fastest-growing emerging economies enjoyed export growth of over $10 \%$ per annum. It also contrasts with the "long 1990s", a period extending from the late 1980's to the mid-2000's during which real global trade flows expanded twice as fast as real GDP growth. The comparison between the pre- and post-crisis period led many public comments, some commentators predicting a stalling of the globalization process by putting forward the concept of "peak trade". The rapid changes in the income-elasticity of trade have therefore been subject to an on-going literature to explain its causes, starting with studies focusing on the "global trade collapse" in 2009. A review of the determinants of trade flows had been necessary in view of the inability of traditional income-based trade models to predict a collapse of trade that has proven to be much larger than the fall in world demand and output. ${ }^{3}$

Since then, the discussion has continued as trade growth, after a rebound in 2010, did not recover from pre-crisis trends, and its elasticity to GDP had slowed down significantly. The relative importance of the "cyclical" and structural/supply-side factors had been further discussed. Weak aggregate demand in advanced economies, linked in particular to the eurozone crisis of 2011-13, has been put forward as a main contributor - a phenomenon amplified by the fact that the share of the euro-zone in world trade is larger than in GDP, thus depressing the former more than the latter. Other researchers emphasized the importance of "structural factors", whereby the slower pace of global value chains expansion, would have significantly affected the expansion of trade. Other major factors, such as changes in the composition of GDP and trade, have been mentioned by the literature.

In this paper, we estimated the standard import equation over the period 1995-2015, using an import intensity-adjusted measure of aggregate demand (IAD), calculated from input-output tables at country level, and compared results with regressions using GDP. We find that the integration of IAD help predict $76 \%$ to $86 \%$ of the changes in values of global imports, a better performance than if using GDP or any other measure of demand, which tend to over-estimate the income elasticity of trade. The use of IAD also enabled us to measure the relative importance of each component of demand, according to their trade intensity. The model is able to account for over $90 \%$ of the recent trade slowdown (2012-2015), with IAD alone explaining $80 \%$ of it. The composition of demand is a primary explanation of trade slowdown because the most trade-intensive components were the ones slowing down the most (such as investment). The slowdown in global value chains explains more than half of the remaining share of the global trade slowdown, not explained by demand factors. Protectionism does not come up as statistically significant.

The paper is structured as follows: Section 2 looks at the literature on the topic. Section 3 introduces the dataset and explains the methodology. Section 4 explains the empirical strategy and presents our results. Section 5 analyses the role of other factors, such as deceleration in trade liberalisation and maturation of global value chains, in the recent

${ }^{3}$ While the average elasticity of trade to global output was 2 between 1990 and 2008, the fall in real global trade flows outweighed that of global output by a factor of 12 in 2009 . This is in sharp contrast with the four large post-war recessions $(1975,1982,1991,2001)$ where world trade dropped "only" 4.8 times more than GDP (Freud, 2009). 
trade slowdown. Section 6 presents the robustness checks. Finally, Section 7 gives a conclusion.

\section{LITERATURE}

The global economic recovery following the 2008-9 financial crisis has been unusually weak on nearly all fronts. It involved both slower-than-expected growth domestically in developed and developing economies, as well as weaker links between these countries, as reflected in the reduction of the rate of growth of international capital and trade flows relative to the pre-crisis crisis (IMF, 2016). The weakness in economic activity, initially confined to European countries, has been spreading to emerging market economies, some of which fell in recession. Activity also softened in China, as prior excesses unwind and the economy rebalanced into a consumption-based one. Economists have suspected "structural" factors to hold back growth, such as slow demographic trends, the "deleveraging" of governments and households' debt, secular stagnation, and increasing concerns about the impact of new technologies on jobs. In this overall picture, the stronger slowdown of trade relative to that of GDP has been much commented, with the literature focusing on the reasons for such a drop in the income/output elasticity of trade.

Discussions about the cyclicality and durability of income elasticity of trade have a relatively long history in economics, and have been the source of a dense literature. Its latest episode, whether the global value chains, aggregate demand or changes in the composition of trade is responsible for the current slowdown, is part of this continuum.

Initially, while many papers focused on the national literature, i.e. reasons for the "high" or "low" income elasticity of demand in particular countries, fewer studies discussed income elasticities in world trade. A seminal paper by Houthakker and Magee (1969) noted the wide differences in the post-war period in income elasticities across OECD countries. Countries such as Japan faced at the time a high elasticity for their exports and a low one for imports, while the United Kingdom and the United States faced a converse situation. The authors argued that there was a concomitance between "favourable" elasticities (such as Japan's) and countries' long term growth rate. They also argued that this asymmetry was durable and "structural", that is, not corrected by real exchange rates changes, a point that was commented by other publications. The paper implied that countries facing lower elasticities had to grow either at a slower rate rather than trading partners, depreciate the exchange rate or face current account deterioration. The paper was commented in subsequent years in its relation to the US growing current account deficit with Japan.

Krugman (1989) acknowledged the empirical regularity of income elasticities of countries and its relationship with long term growth found by Houthakker and Magee (1969). He also recognized that "although an income-and-price elasticity framework should give rise to substantial shifts in equilibrium real exchange rates over time, in practice the income elasticities turn out to be just right to make this unnecessary. I will refer to this empirical regularity as the 45 degree rule". He attributed the 45-degree rule (the absence of strong real trends in real exchange rates) to supply-side effects, whereby "it is necessary to suppose that there is not much comparative advantage among industrial countries and that their specialization at any point in time is largely arbitrary specialization due to increasing returns rather than comparative advantage". Apart from increasing returns he also explains the 
persistence of the 45-degree rule, in a monopolistic competition model, to product differentiation. Empirical evidence was based on a sample of 8 industrialized countries.

The 45-degree rule has not been accepted by all economists (see Wu (2005)). However, the concept of product differentiation made its way into measured income elasticity. Feenstra (1994) noted the expansion in the range of new imports from rapidly growing trading partners, and observed that import prices indices did not capture the new product varieties and decrease in import prices - which resulted in over-estimation of measured import elasticities. He demonstrated how to incorporate new product varieties into a constant-elasticity-of-substitution aggregate of import prices, leading to corrected indexes.

The composition of trade has become more important in the literature of the 1990s and 2000's, both with the expansion of global value chains, and the availability of more granular data. Based on moving averages, figure 1 shows the acceleration of trade relative to output from the late 1980's to mid-2000's. The literature emphasised the increased ability of large companies to allocate tasks across countries according to comparative advantage as a potential reason for this strong trade growth. This process was helped by other factors such as the liberalization of trade and investment policies, falling transportation and other trade costs, and the declining relative prices of tradables. As a result, the import content of exports increased for both developing and developed countries.

Figure 1: The relationship between GDP and world trade (exports), 10 year moving averages

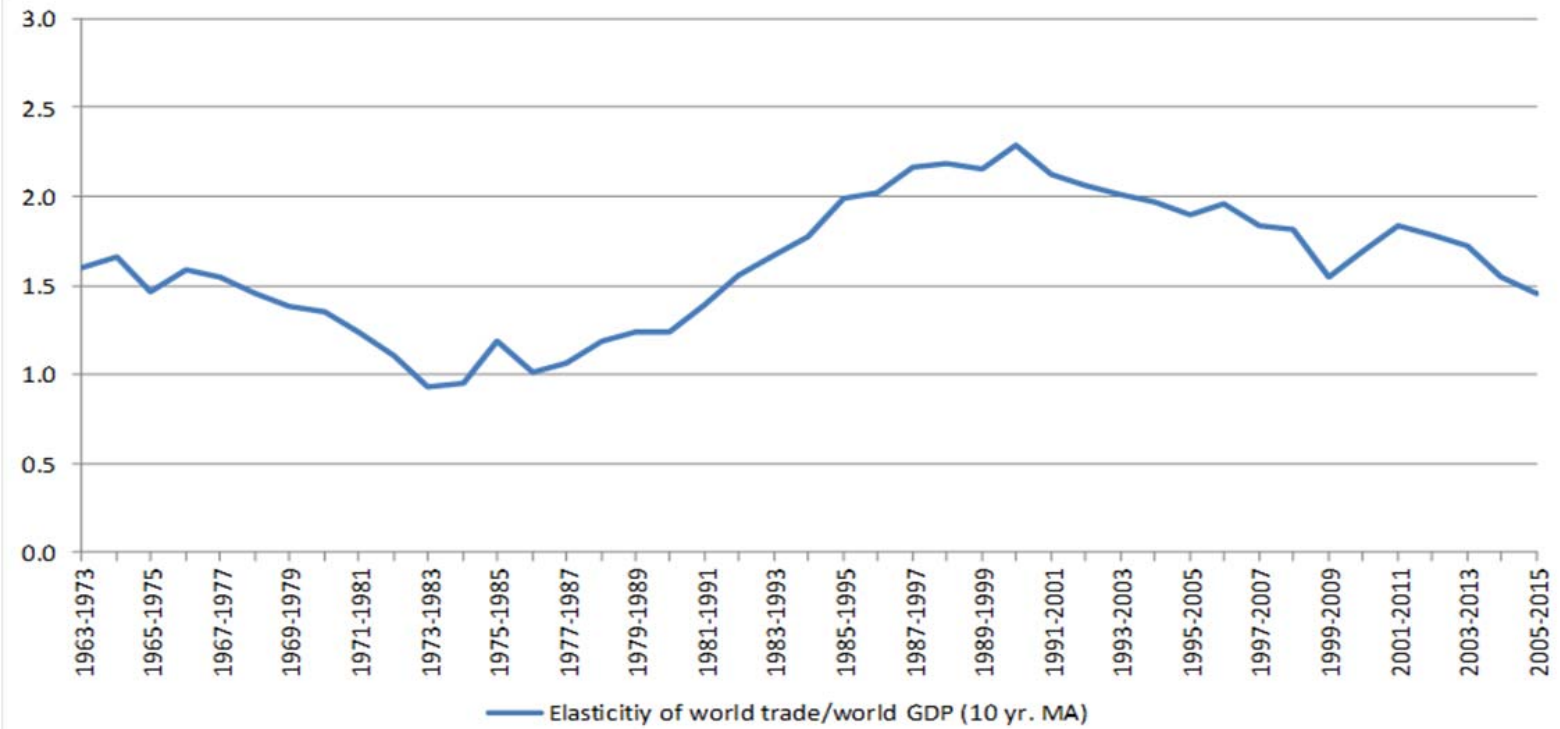

Source: WTO International Trade Statistics, IMF World Economic Outlook for GDP at market exchange rates.

With growing trade and investment linkages between increasingly economicallyintegrated regions, the effects of lower demand in one of the world's main economy spilledover exponentially to partner economies through lower imports. Still, the way in which the US recession turned into a "great trade collapse" in 2009 surprised the economist community. This event led to significant research. Subsequently, economists also went in search for the way the income elasticity slowed down significantly, during the following period of slow economic recovery (2011-15). The elasticity between real GDP growth and trade had fallen to (barely) 1, raising about peak trade, de-globalization, and demand spill-overs. 
Comparisons were made with previous periods of unit or negative elasticity, which had been marked by a combination of recession, protectionism and non-cooperative economic policies, notably during the 1970s to mid-1980s. Articles argued that economic crises had muting effects on trade, which may eventually persist in the medium term (Freund, 2009).

When looking at the dense literature of the past 7-to-8 years, one could look at the following contributions.

Baldwin (2009) provided a forum and a summary of the early and rich literature on the "great trade collapse". He highlighted the convergence of views on the central role of real final demand (Bems, Johnson and Yi, 2013). The effect of falling demand had been amplified by the existence of highly integrated and synchronized production networks (Di Giovanni and Levchenko, 2009 and Yi, 2009), which eventually contributed to spread the effects of stumbling trade-intensive durable goods. The role of demand, and that of the composition of trade, was also highlighted by Eaton et al. (2016). They calculated that two thirds of the drop in trade, relative to GDP, could be attributed to the shift in spending away from manufactures, particularly from durables. Alessandria, Kaboski and Midrigan (2010) also argued that a strong inventory adjustment had taken place in the industries in which the demand shock was the greatest. On the whole, other, supply-side factors accounted for much less of the global trade collapse, although difficulties in obtaining (trade) finance were mentioned by Bhagwati (2009), Amiti and Weinstein (2011), Chor and Manova (2012) and Auboin (2014). Other factors, such as the increased use of protectionism, have also been highlighted by Evenett (2009).

Constantinescu, Mattoo and Ruta (2015) suggested that while short term determinants such as weak global demand were dominant during the financial crisis and the first year of the recovery, the decline of the long-run world trade elasticity - which started out in the early 2000's according to the authors - explains more than half of the 2012-2013 global trade slowdown. This decline in the long-term elasticity of trade can be attributed, according to the authors, to the slowing pace of international vertical specialization (global value chains) rather than increasing protection or the changing composition of trade and GDP. Among other evidence, they consider that the post-crisis reduction of the gap between the trade-toincome elasticities for value-added and gross trade suggests that global value chain expansion was slowing down.

In the line of thoughts developed by Eaton et al. (2016), Bussière et al. (2013) have adopted an original approach to incorporate the changing patterns of trade into the analysis of demand. Rather than using a standard import demand model, which prediction value has considerably declined since the global trade collapse, they constructed an import-intensityadjusted measure of aggregate demand. This measure weights each component of aggregate expenditure (consumption, government expenditure, fixed capital investment, exports) by their import intensity, computed from OECD input-output tables. Looking at data from 18 OECD countries in the period 1985-2011, their model, incorporating the import-intensity measure, explains $80 \%$ of the average fall in imports of the G7 countries' imports during the great trade collapse. The authors deny any "puzzle" in the fall of world trade observed during the financial crisis, and conclude that "trade fell mostly because demand crashed globally and did so particularly in its most import-intensive component" (Vox column by Bussière et al., 2012). 
Beyond the improved prediction performance of their model, their methodology introduced an element of trade dynamics in demand-based modelling - with the weights increasing during periods of rising dependence of output on imported input, while falling during less trade-intensive periods (for example the current transition of the Chinese economy towards a more consumption and service-based economy).

Bussière's (et al.) methodology was used in the most recent contributions on the decline in trade income elasticities. IMF (2016) found that "the overall weakness in economic activity and aggregate demand, in particular in investment, has been the primary restraint on trade growth, accounting for up to three-fourths of the overall slowdown." Using the import-intensity measure of demand as part of their import demand model, they explained three-quarters of the global goods import growth decline in the period 2012-15, relative to the period 2003-2007, by changes in economic activity. They also found that the predicted values for the period 2012-2015 on world imports were higher than the actual - this was especially true for goods relative to services. They called the difference between the two the "missing import growth". Most of this "missing import growth" was found to be in developing economies, suggesting that the weak economic activity and its composition was unable to fully account for the recent slowdown in trade, especially in these countries. While the impact of other factors was generally limited, they found that the decline in the growth of global value chains in the observed slowdown was significant.

Haugh et al. (2016) and ECB (2016) showed relatively similar findings but in different proportions. The result of Haugh et al. (2016) regressions suggested that weak demand, on the one hand, as captured by output gaps and investment growth, and the slowdown in global value chains expansion, on the other, accounted for roughly equal proportions to the global trade slowdown (about $40 \%$ each). The third largest factor was the slowdown in the pace of trade liberalization. ECB (2016) emphasizes these two categories, structural (global value chains) and non-structural (the demand channel). The non-structural category, re-named compositional changes, encompassed both the shift of growth in trade and economic activity towards economies with lower trade intensity (i.e. developing and emerging economies), and changes in the composition of aggregate demand towards less trade intensive-component. The other source of change is related to structural factors such as less reliance on GVCs and slower trade liberalization. According to the ECB, compositional effects explained a bigger half of the decline in the global income elasticity of trade, while structural factors accounted for the smaller half.

\section{CALCULATING THE IMPORT INTENSITY-ADJUSTED DEMAND}

\section{III.1 Methodology and data}

Like other papers, we followed the innovation introduced by Bussière et al. (2013) with a view to updating and improving it. The fact that using the trade-weighted shares of aggregate expenditure components improves the prediction value of demand-based import models indicated that the import-component of demand plays an increasing role in explaining cyclical behaviours in open economies.

\section{Methodology}


In a first step, in this section, we computed the total import content of final demand expenditure (private consumption, gross fixed capital formation, government consumption and exports) using Input-Output tables, explained in detail in Box 5. ${ }^{4}$ In a second step, by weighting each component of expenditure in each economy with its import content, we calculated the import-intensity adjusted demand (IAD) in the way that is described below. In the next section (section IV), we used the import-intensity adjusted demand in the import demand function in lieu of GDP and other usual determinants.

Figure 2: Import content of an expenditure component for country A.

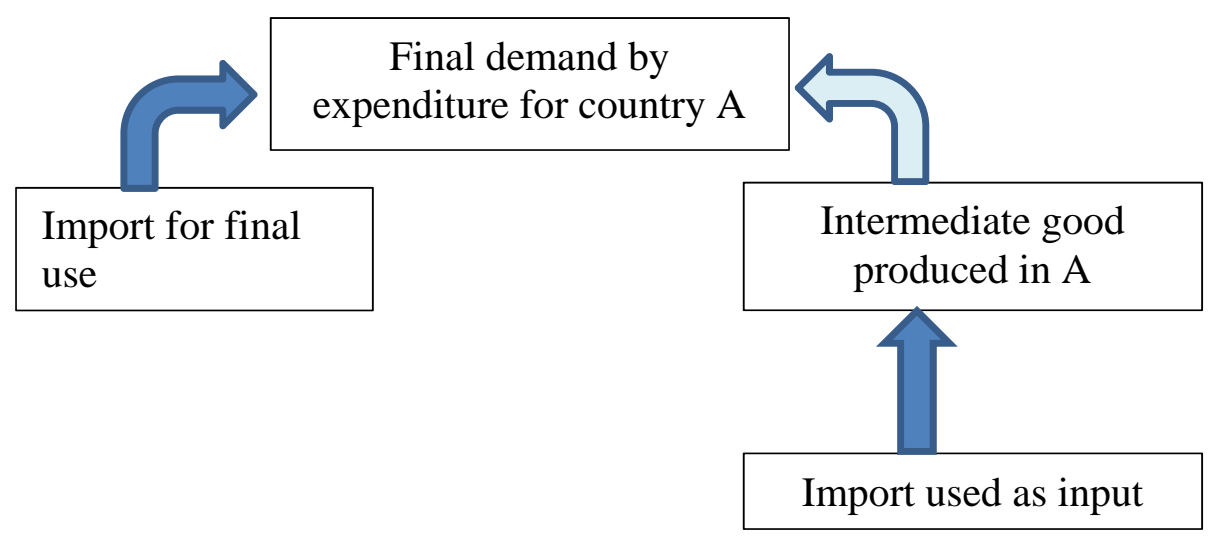

As shown in figure 2, the total value of imports for each expenditure component is given by the sum of imports of final goods and services for final use/demand, i.e. direct imports, and imports of inputs required by domestic industries to produce an output which will either be absorbed domestically or exported (indirect import). The distinction between direct and indirect imports is allowed by the use of national Input-Output (I-O) tables in a way described by the matrices simplified in Box 5.

For each expenditure component $k$, national Input-Output tables are used to calculate the value of direct imports $\left(M_{k}^{\text {dir }}\right)$ and the value of indirect imports $\left(M_{k}^{\text {indir }}\right)$. The total value of imports of each expenditure component $\left(M_{k}\right)$ is then given by:

$$
\mathbf{M}_{\mathbf{k}}=\mathbf{M}_{k}^{\text {dir }}+\mathbf{M}_{\mathbf{k}}^{\text {indir }}
$$

With k= Private consumption, Government consumption, Investment, Exports

The total import content of each expenditure component $k\left(\omega_{k}\right)$ is then calculated by dividing the total value of imports of each expenditure component $k\left(M_{k}\right)$ by the total final demand for domestic output (value added) plus imports, for the respective expenditure component $\left(F_{k}\right)$ :

${ }^{4}$ Although we are aware that investment does not coincide with Gross Fixed Capital Formation (GFCF), the fact that changes in inventories are highly volatile prevented us from the construction of the import contents of changes in inventories. Therefore, we will use the term investment instead of GFCF in the rest of the paper. 


$$
\omega_{k}=\frac{M_{k}}{F_{k}}
$$

Equivalently, combining equations (1) and (2), we obtain:

$$
\omega_{k}=\frac{M_{k}^{d i r}+M_{k}^{\text {indir }}}{F_{k}}=\frac{M_{k}^{d i r}}{F_{k}}+\frac{M_{k}^{\text {indir }}}{F_{k}}=\omega_{k}^{d i r}+\omega_{k}^{i n d}
$$

Where, the total import content of each expenditure component $\left(\omega_{\mathrm{k}}\right)$ is the sum of the direct $\left(\omega_{\mathrm{k}}^{\mathrm{dir}}\right)$ and indirect $\left(\omega_{\mathrm{k}}^{\mathrm{ind}}\right)$ import contents. The indirect import content of each aggregate expenditure component represents the share of intermediate imported inputs per unit of final demand, while the direct import content represents the share of imported final goods and services per unit of final demand. ${ }^{5}$ In section IV, we will use this decomposition to distinguish the contribution of direct and indirect import demand in the recent trade slowdown.

The import-intensity-adjusted demand (IAD) was thus constructed country-bycountry as a weighted average of traditional aggregate demand components:

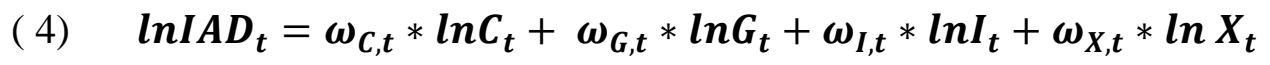

Where, C stands for private consumption, $G$ for government consumption, I for investment and $\mathrm{X}$ for exports. The weights $\left(\omega_{k, t}\right.$, with $\left.k=C, G, I, X\right)$ are the total import content of each of the four final demand expenditure components (C, G, I or X) and they are constructed as explained above. Weights are time varying and normalised in each year so that they sum up to 1 .

As indicated in IMF (2016), "this approach explicitly account for differences in the import content of the aggregate demand components and captures the effects of changes in the overall strength of economic activities and across its drivers". While Bussière et al. (2013) made such calculation for 18 OECD countries, we have extended it to a set of 38 countries, accounting for more than $75 \%$ of world trade volumes in 2015. Such calculations incorporated in particular developing countries that are not members of the OECD, such as the "BRICs" (Brazil, Russian Federation, India and China) and other emerging market economies in Asia and Latin America. By doing so, we have been mindful that the recent rebalancing of some important developing economies (such as China's) away from investment and manufacturing, towards consumption and services, was likely to reduce the import intensity of demand in these countries. Another expectation was that, over time, with globalization, the trade-intensity of some demand components such as exports and investment was increasing. For consumption and government expenditure, we thought that the increase might have been slower although this depended on the level of openness of economies and participation to trade agreements (in particular those agreement promoting more open and efficient procurement practices).

${ }^{5}$ Note that the direct import content of exports is zero as we excluded re-exports of goods and services from our analysis. We are aware that for some countries, such as China and other emerging economies, this assumption might be a bit problematic due to the high amount of processing trade; therefore in these countries we are likely to bias downward the total import content of exports. 


\section{Data}

Bussière et al. (2013) calculations of import content of final demand expenditures were limited by the shortage of input-output data for years before 1995 and after 2005. At the time of their work, the OECD input-output (I-O) database provided data for only three benchmark years, 1995, 2000 and 2005. With I-O tables being available only every five years, the authors interpolated linearly the available points to construct weights for other years. For the period after 2005, the authors simply used the 2005 data forward. Since then, the World Input-Output Database (WIOD) has been created under an EU-funded project and made available to users. We therefore decided to use WIOD data, not the least because OECD I-O tables, which do not contain new data, would have meant a significant loss of information (weights have varied quite a bit since 2005) relative to WIOD.

We therefore used the 2016 WIOD database, with 2014 as the last available data year. It contains annual time-series of world input-output tables, comprising national input-output tables connected by bilateral international trade flows. By comparison, OECD I-O tables and the Trade in Value Added database (TiVA) only compiled data for particular benchmark years. The WIOD also covers a larger number of countries (forty-three), including all $28 \mathrm{EU}$ countries, the United States, Japan, Canada, and the main emerging market economies (including the BRICs). The WIOD database provides a model for the rest-of-the-world. ${ }^{6}$ We were able to calculate the annual import content of the four components of aggregate demand for 38 countries from 1995 to 2014, accounting for around 83\% of world GDP and 76\% of world trade volume in 2015. ${ }^{7}$ The results of our calculations are presented in Figure 3, 4, 5 and 6 below.

\section{III.2 Results}

\section{III.2.1 Import weights and content}

Figure 3 shows the evolution of the average total import content of the four GDP expenditure components (private consumption, government expenditure, gross fixed capital formation and exports) in the 38 countries analysed, over the period 1995-2014. The most pro-cyclical components of aggregate demand, i.e. investment, exports and private consumption, are also found to be most import intensive; net government expenditures are less so.

${ }^{6}$ In addition, the WIOD has been constructed in a clear conceptual framework on the basis of officially published input-output tables in conjunction with national accounts and international trade statistics and therefore, it ensures a high level of data quality, partially at the expense of coverage in term of the number of countries covered. The industry classification of the WIOD 2016 release is based on the ISIC Rev. 4 system and it covers 56 sectors: including agriculture, mining, construction, utilities, manufacturing industries, and services industries.

${ }^{7}$ For 2015 we assumed the same import content as in 2014. The 38 countries included in our analysis are: 26 European countries (Austria, Belgium, Bulgaria, Cyprus, Czech Republic, Denmark, Estonia, Finland, France, Germany, Greece, Hungary, Ireland, Italy, Latvia, Lithuania, Luxemburg, Netherland, Poland, Portugal, Romania, Slovak Republic, Slovenia, Spain, Sweden, UK) and 12 other major countries (Australia, Brazil, Canada, China, India, Indonesia, Japan, Mexico, Russia, South Korea, Turkey, and the United States). 
Figure 3: Evolution of average import content of aggregate demand components for all sample countries

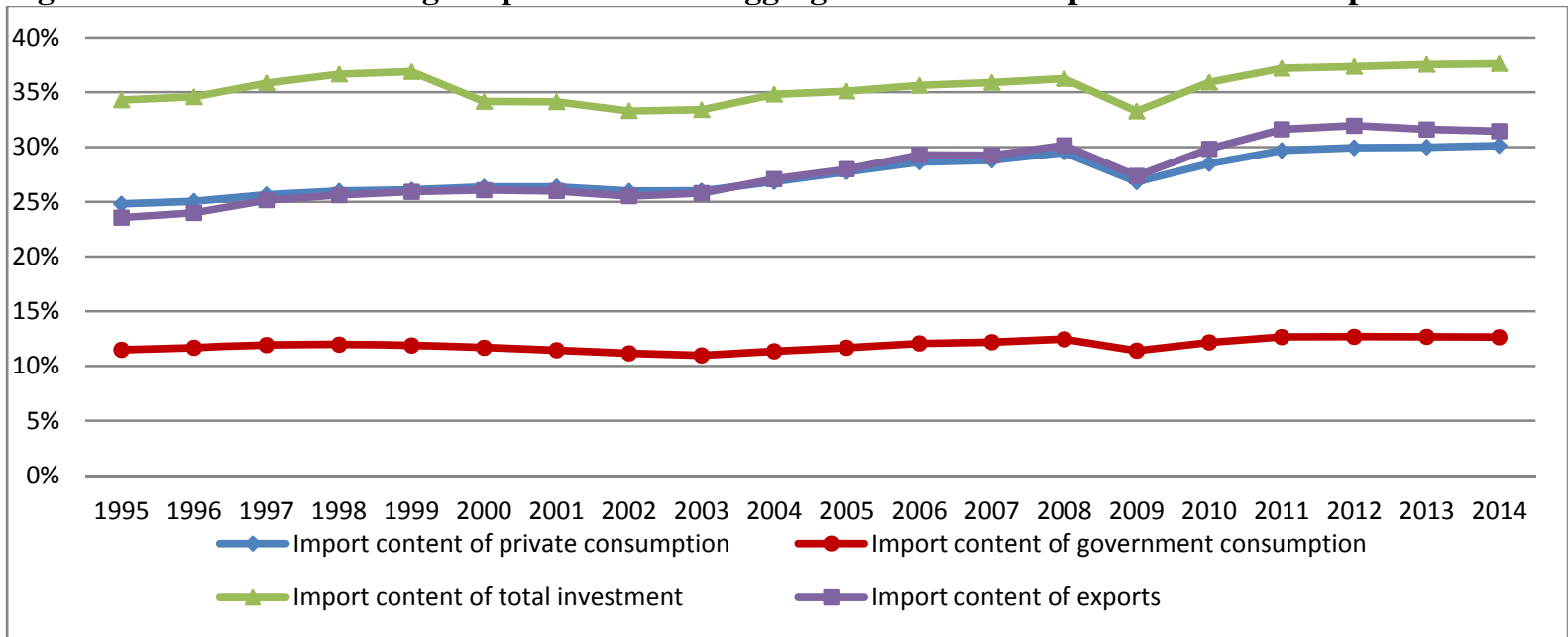

Source: WIOD Input-Output tables and authors' calculations

Investment is the most import-intensive component of domestic demand, with an average import content (for all 38 countries) of 37\% between 1995 and 2014, although the overall import content of exports and of private consumption have been the two components of demand growing the fastest over this period. The general increase in the import content of aggregate demand reflects the growing openness of our economies, falling trade costs, and international production fragmentation. There was a drop in import-intensity during the global financial crisis of 2008-2009, followed by a very slow recovery afterwards. Since then, investment has continued to be the most import-intensive component of GDP; the import intensity of exports and private consumption slightly increased in recent years (figure 3).

Figure 4: Import content of aggregate demand components between 1995 and 2014

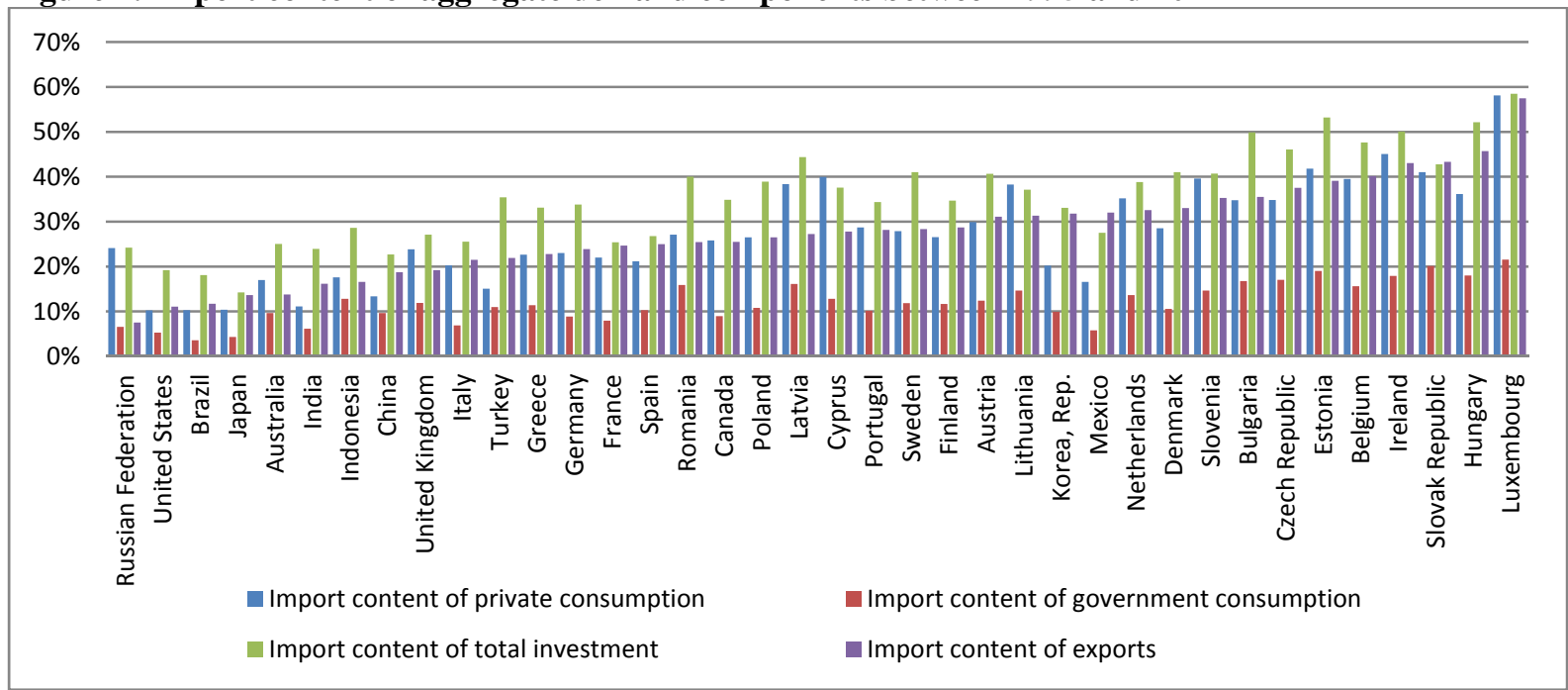

Source: WIOD Input-Output tables and authors' calculations

Figure 4 shows that the import content of aggregate demand components varies across countries. For smaller, outward-oriented economies, the import content of exports is particularly high (Belgium, Luxembourg). It is lower for countries with substantial exports in 
natural resources since these activities require fewer intermediate goods in the production process. Figure 5 details the evolution of import intensities for three major trading nations, the USA, China and Japan. Relative to other advanced economies, the United States and Japan display lower import intensities, reflecting the large pool of domestic intermediate suppliers. However in Japan, the import content of all aggregate demand components has been rising significantly over the past two decades (Figure 5). The import content of investment and private consumption, in particular, increased fourfold between 1995 and 2014 (Figure 5).

In China the import intensity of GDP components has followed a different pattern. Import-contents peaked in mid-2000s and have followed a downward trend since then, despite a short-lived recovery in 2010-2011. This declining trend in the import content since 2005 might partly reflect the rebalancing of China's economic growth towards the domestic consumption of non-tradables, mostly services (rent, business and private services). On the production side, this rebalancing has coincided with the rapid expansion of the services sectors, which is less import and investment intensive, relative to manufacturing (with the earlier outpacing the later in 2015). 
Figure 5: Selected economies' evolution over time of import content of main GDP components

\section{China}

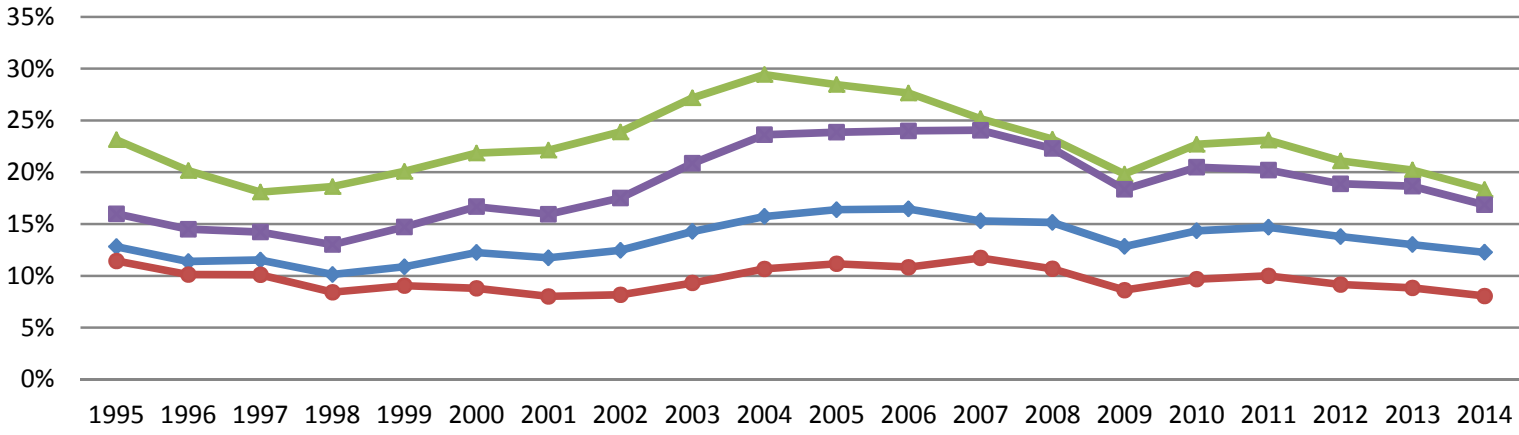

Japan
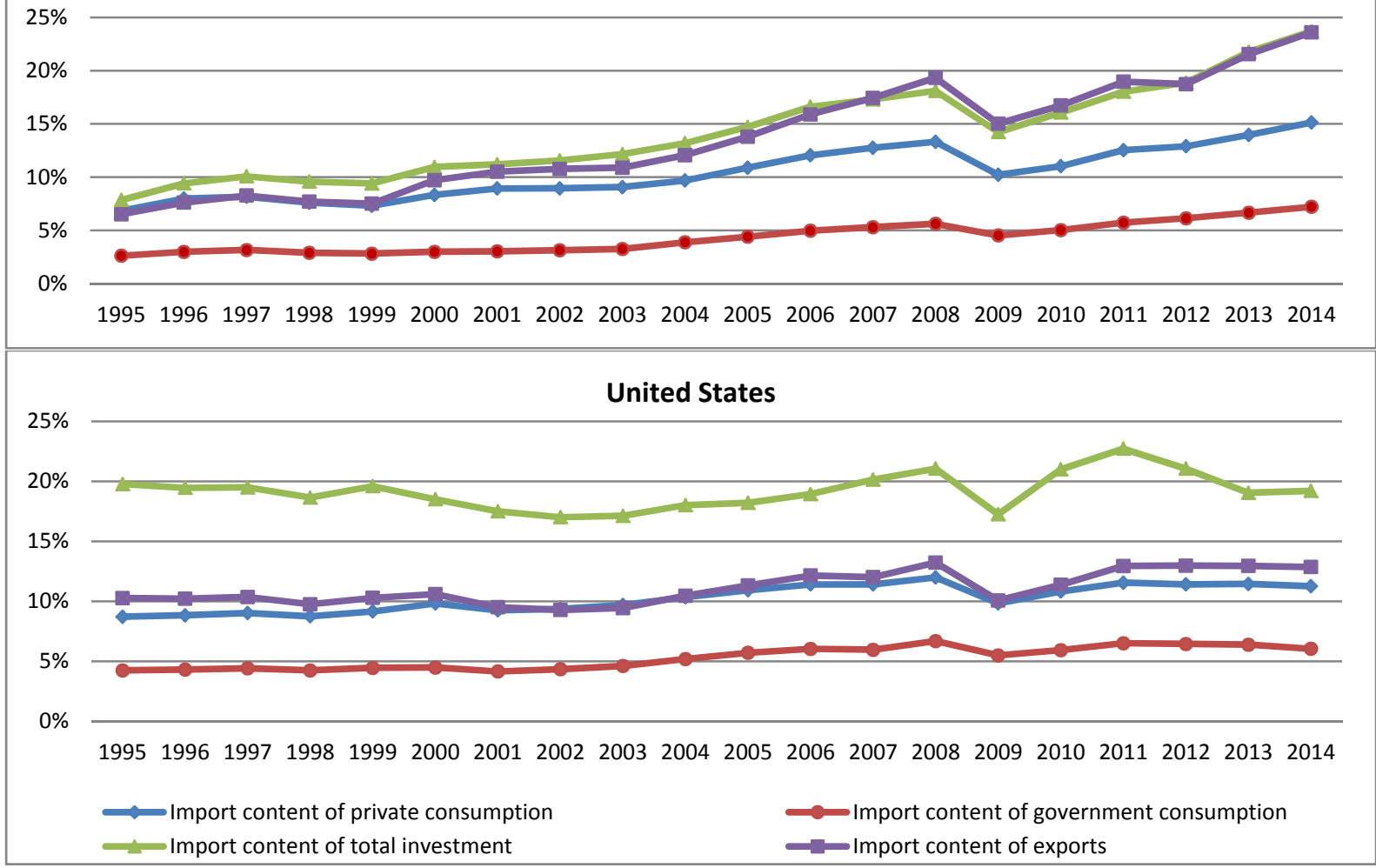

Source: WIOD Input-Output tables and authors' calculations

\section{III.2.2 Import intensity adjusted demand (IAD)}

As indicated just above, import-intensity-adjusted demand (IAD) is the weighted average of aggregate demand components multiplied by their import contents (weights).Table 1 below shows annual changes for IAD relative to real GDP and real imports of goods and services (M) for advanced economies, on the one hand, and developing and emerging economies, on the other, over the entire sample period. Blended by imports, IAD is a measure of demand which is somewhat more volatile than GDP. 


\begin{tabular}{lccc}
\hline \hline & GDP & IAD & M \\
\hline advanced economies & & & \\
Mean & 2.4 & 3.2 & 5.2 \\
Std. Dev. & 3.3 & 5.0 & 7.9 \\
Min & -16.0 & -27.1 & -38.1 \\
Max & 11.2 & 18.2 & 25.9 \\
Obs & 520 & 520 & 520 \\
developing and emerging economies & & & \\
Mean & 3.9 & 4.9 & 7.1 \\
Std. Dev. & 4.0 & 6.5 & 11.8 \\
Min & -14.1 & -26.4 & -52.2 \\
Max & 21.4 & 20.6 & 32.0 \\
Obs & 240 & 240 & 240 \\
\hline \hline
\end{tabular}

Note: The table presents descriptive statistics from the log difference of GDP, IAD, real import of goods and services (M). All values are reported in percent unit. The dataset covers annual data from 1995 to 2015 for 38 countries.

Figure 6 shows that in the BRICs, IAD growth had been slower than real GDP growth in recent years. A similar trend was observed in developed economies, as a result of lower growth in investment and exports, which are the two most import/trade intensive elements of economic activity (as shown in section III.2.1).

Figure 6: GDP and IAD for BRICs

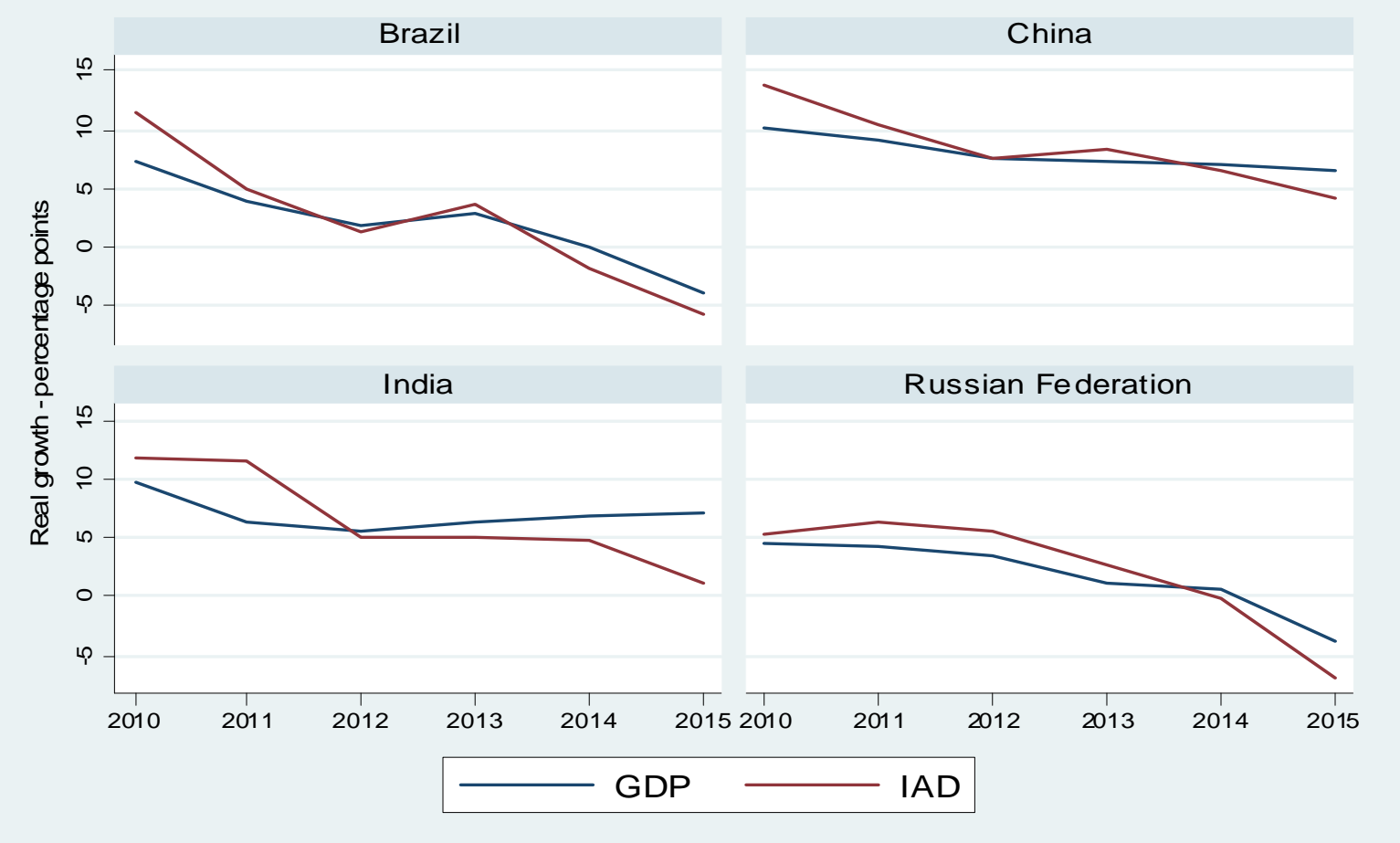

Source: World Development Indicator (WDI) (World Bank), WIOD input-output table and authors' estimates. 


\section{EMPIRICAL STRATEGY}

The construction of import-intensity adjusted demand indicators aims at better understanding the drivers of trade growth, in particular its recent slowdown, and to look at the role of changes in the composition of import-weighted aggregate expenditure to explain such changes in global trade. Given the lower predictive power, in recent years, of GDP and other measures of demand on global trade, the substitution of IAD into the standard import model has been providing, as explained below, for improved quantitative and qualitative information.

In sub-section IV.1, we estimated the standard import equation over the period 1995Q1-2015Q4 using IAD as the measure of aggregate demand and compared the results with regressions using GDP. The integration of IAD improves the performance of the equation. The panel based-model using IAD predicts on average $76 \%$ of the changes in import of goods and services during the period 1995Q1-2015Q4, while the country-by-country regressions of the same model predicts $86 \%$ of the changes. Models using GDP explained respectively $63 \%$ and $80 \%$ of the changes in real imports. In addition, the estimated elasticities of import to demand are less volatile when using IAD compared to GDP.

In sub-section IV.2, we looked at the role of IAD in explaining the recent trade slowdown, notably during the period 2012-2015. Results of the regressions show that the model can account for over $90 \%$ of the slowdown for the average economy. IAD alone explains around $80 \%$ of the recent global trade slowdown.

\section{IV.1 The Main model}

We have regressed the year-on-year growth rate of real import of goods and services for each of the 38 countries $\left(\Delta \ln M_{c, t}\right)$ on their year-on-year growth rate of import-intensity adjusted demand $\left(\Delta \ln I A D_{c, t}\right)$ and changes in their real effective exchange rate $\left(\Delta \ln R E E R_{c, t}\right)$, as a proxy for relative price and competitiveness changes. ${ }^{8}$ We added country dummies $\left(\gamma_{c}\right)$, in panel regressions, to account for countries heterogeneity. Lags of the dependent and explanatory variables' growth rates are also included in the model to allow for richer dynamics. We used panel and country-by-country regressions. The former calculates one aggregate income and price elasticity for imports of all 38 countries, whereas country-bycountry regressions calculate elasticities for each country present in the regression (the results presented in Table 3 are simple averages of such elasticities for the countries concerned). ${ }^{9}$ Since all variables are expressed in logs, coefficients may be interpreted as elasticities.

The periodicity for all these variables is quarterly, and regressions have been run over the period 1995Q1-2015Q4. Regarding the construction of IAD for each country, since the IO tables allow us to compute the import weights only every year, we assumed the import weights did not change in the four quarters that compose each of the years. The components of aggregate demand (private and government consumption, gross fixed capital formation and

\footnotetext{
${ }^{8}$ We carried out a set of unit root tests (Augmented Dickey-Fuller test or Phillips-Perron test) for all the variables involved in the regression. Overall, results confirm that our time series appear non-stationary in level and stationary in first difference. Therefore, we used all variables in first difference in equation (5). As we used the growth rates for all the variables in our regressions, co-integration did not turn to be a major issue.

9 In country-by-country regressions, we have used the Newey-West (1987) estimator to correct for heteroskedacity and autocorrelation.
} 
exports of goods and services), all in volume, are pulled from quarterly national accounts from the OECD and EUROSTAT. Data on import of goods and services, in volume, also come from quarterly national accounts of OECD and EUROSTAT, however, when later we distinguished between goods and services (section IV.3), trade data was extracted from the World Trade Organization's Statistics database. The real effective exchange rates (CPIbased) used as an indicator of competitiveness/relative price changes are obtained from the Bruegel Institute's database.

The main specification tested, both for panel and country-by-country regressions, is as follows:

( 5) $\quad \Delta \ln M_{c, t}=\beta_{I A D} \Delta \operatorname{lnI} I A D_{c, t}+\beta_{R E E R} \Delta \ln R E E R_{c, t}+\beta_{I A D, l} \Delta \ln I A D_{c, t-1}+$ $\beta_{R E E R, l} \Delta \ln R E E R_{c, t-1}+\beta_{M} \Delta \ln M_{c, t-1}+\gamma_{c}+\varepsilon_{c, t}$

Where: $\Delta \ln M_{c, t}$ is the year-on-year growth rate of real imports of goods and services for 38 major trading nations, $\Delta \operatorname{lnI} A D_{c, t}$ is the year-on-year growth rate of import-intensity

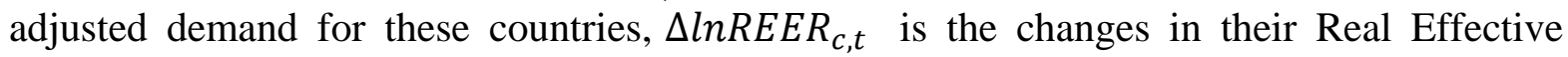
Exchange Rate (as a proxy for relative price and competitiveness changes), $\varepsilon_{c, t}$ is the error term.

\section{Panel analysis}

Panel regressions estimated the average import-elasticity of IAD to be about 1.5 over the period 1995-2015, against around 2 using real GDP (Table 2). The smaller elasticity of imports to demand when using IAD confirms the results of recent studies that take into account the internationalization of production processes. The real effective exchange rate (REER) is positively correlated with real imports, suggesting that when the REER increases, that is the exchange rate of the country under study appreciates, imports are cheaper and increase in real terms. When it depreciates, imports decrease. In Table 2, time t REER is not statistically significant, but lagged REER is, which is consistent with the literature (exchange rates changes tend to affect trade demand over time). The panel regression using IAD performs much better compared to GDP in term of goodness of fit, with R-squared being higher by around 0.2 .

Table 2: Panel regression's estimation results

IAD specification

\section{$1.503 * * *$}

(0.056)

$0.080 * * *$

(0.028)

0.058

(0.125)

Constant

$0.009 * * *$

(0.003)

2,859

Observations
GDP specification

$2.082 * * *$

$0.149 * *$

(0.060)

0.055

(0.158)

0.003

(0.004)

2,859 
Note: The table shows estimates of panel regressions from equation 5, performed on the full set of 38 countries between 1995Q1 and 2015Q4. To save space we did not report the point estimates of the lagged value of the dependent variable and Import Demand. Robust standard errors in parentheses $* * * \mathrm{p}<0.01$, $* *$ $\mathrm{p}<0.05, * \mathrm{p}<0.1$

For each country-year, we obtained the real import growth predicted by our model, $\left(\Delta \widehat{\operatorname{lnM}}_{c, t}\right)$, by applying the estimated coefficients of equation (5) to the actual data. The predicted real import growth for each country-year was given by the following condition:

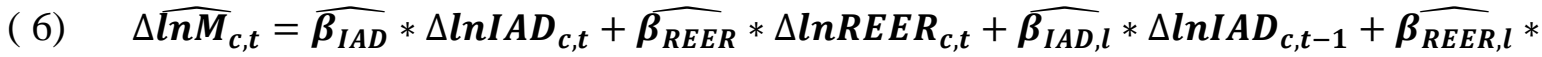
$\Delta \ln R E E R_{c, t-1}+\widehat{\beta_{M}} * \Delta \ln M_{c, t-1}$

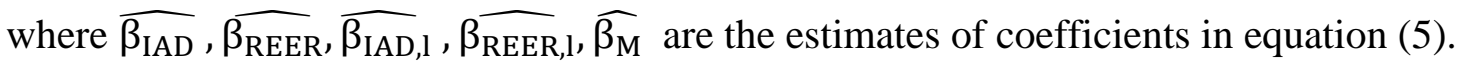

The average actual and predicted real import growth was then calculated as the weighted average of country-specific real import growth rates, where nominal import shares between 2005 and 2014 were used as weights.

Figure 7 presents the actual average real import growth in the 38 countries analysed together with the predicted average real import growth, using either GDP or IAD as proxy for demand. The empirical model tracks real import growth quite closely. The model slightly over-predicts real import growth in the global trade collapse and from 2012 onwards, although less for IAD than for GDP.

Figure 7: Actual and predicted evolution of real goods and services import growth: full sample

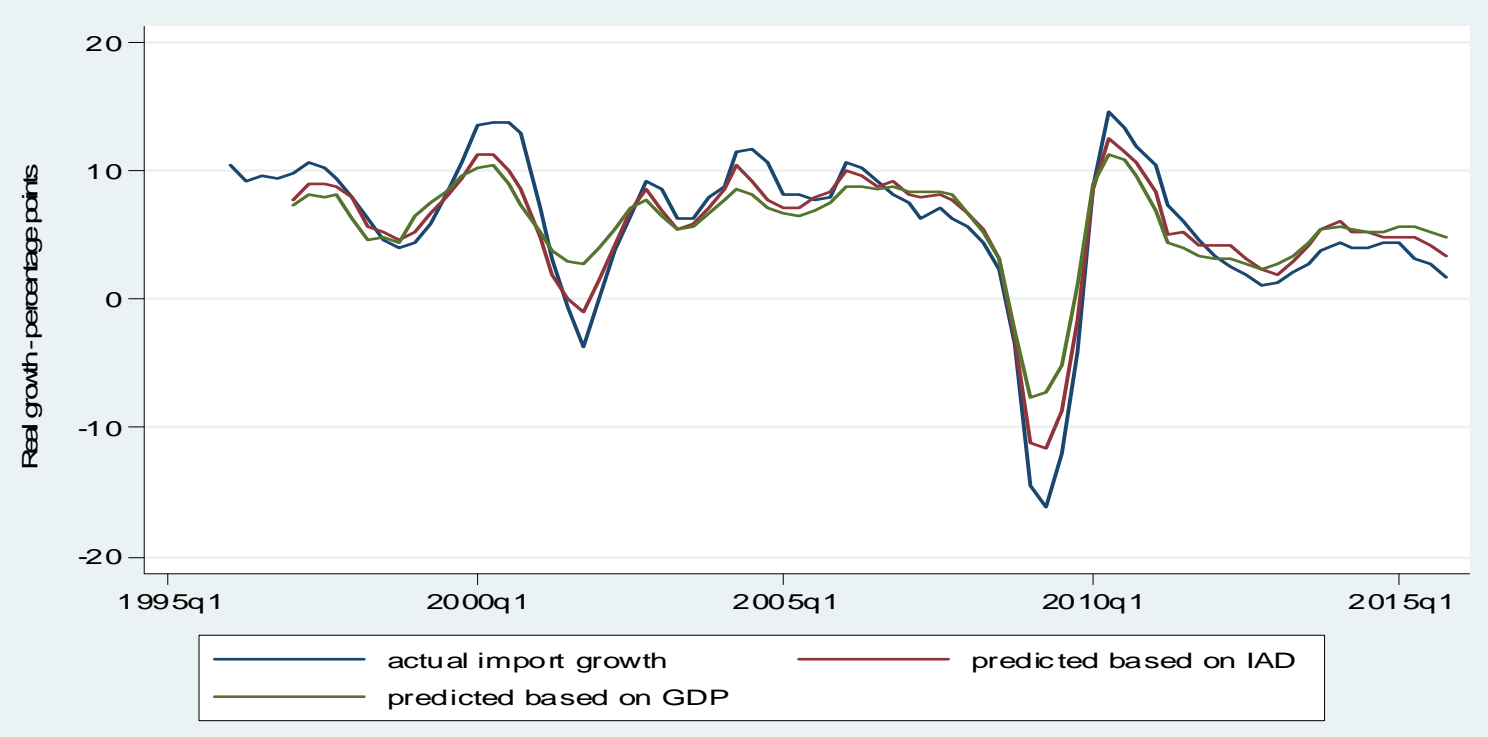

Note: The blue line shows the weighted average of country-specific actual real import growth. The green line shows the weighted average of country-specific fitted value based on panel regression, using GDP as measure of demand. The red line shows the weighted average of country-specific fitted value based on panel regression (equation 5), using IAD as measure of demand. 
Over the entire sample period 1995Q1-2015Q4, the panel based-model using IAD predicts on average $76 \%$ of the changes in import of goods and services during the period 1995Q1-2015Q4, compared to 63\% explained by the model using GDP. The model based on IAD takes a better account than GDP of the lower import elasticity of demand over the very last years of the period under review, stemming notably from developing and emerging economies (Section III and V).

We also re-estimated regression of the form of equation (5) with 10 years rolling windows in order to explore the presence of structural break in demand elasticities. The figure below shows the evolution of panel import elasticities to IAD and GDP over the period 1995:IV to 2015:IV. The empirical model using IAD as proxy of demand yields estimated elasticities of imports to demand that are significantly less volatile compared to the one using GDP. This suggests that using GDP as a demand measure in trade equation may indicate structural breaks in the estimated elasticity even when this is not the case when using IAD.

Figure 8: Evolution of import demand elasticities over time

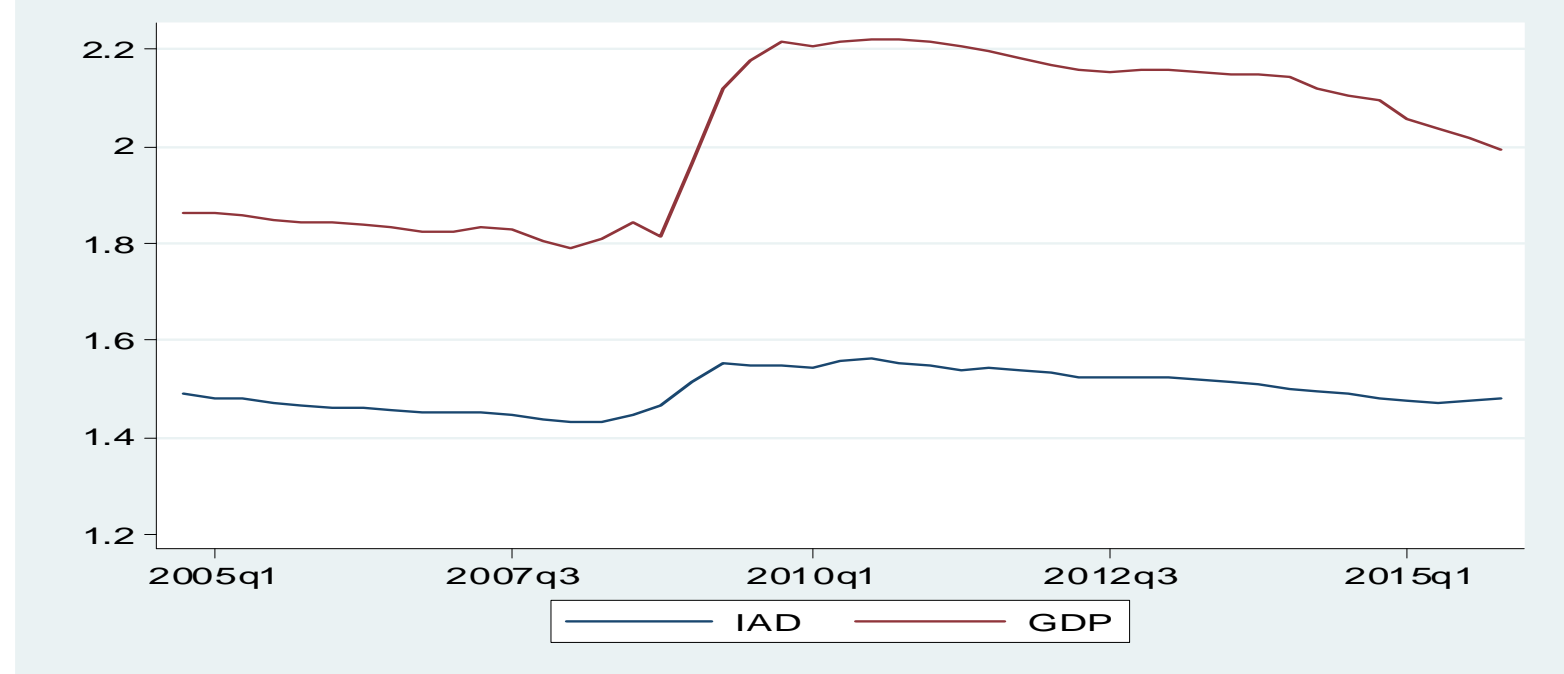

Note: The figure shows the evolution of the contemporaneous coefficient of the two demand measures, GDP and IAD, using panel regression from equation (5), with 10 years rolling windows. Dates in the $\mathrm{x}$-axis correspond to the final quarter of each of the 10 years rolling windows.

\section{Country-by-country analysis}

There is some heterogeneity across countries, as could be expected. Therefore, we estimated the model separately for each of the 38 countries (country-by-country regressions). Table 3 shows relatively similar results as Table 2 in terms of average elasticities (around 1.5 for IAD and a bit over 2 for GDP).

However, country-by-country regression allows for a better differentiation between categories of countries, showing greater dispersion and volatility in the import elasticities of demand. As shown in Table 4, advanced economies have on average slightly higher elasticities than emerging and developing ones (1.60 versus 1.49$){ }^{10}$ The REER is not always

10 Developing and emerging economies as well as advanced economies are defined based on the IMF's World Economic Outlook classification. Our sample covers 26 advanced economies (Austria, Belgium, Czech Republic, Denmark, Estonia, Finland, France, Germany, Greece, Ireland, Italy, Latvia, Lithuania, Luxemburg, 
positive and statistically significant, depending on countries (the negative value here is an average of the country-by-country coefficients).

Table 3: Country-by-country regression's estimation results

\begin{tabular}{|c|c|c|c|c|c|c|}
\hline & \multicolumn{3}{|c|}{ IAD specification } & \multicolumn{3}{|c|}{ "GDP specification } \\
\hline & $\begin{array}{r}1 \mathrm{st} \\
\text { quartile }\end{array}$ & mean & $\begin{array}{l}\text { 3rd } \\
\text { quartile }\end{array}$ & $\begin{array}{r}1 \mathrm{st} \\
\text { quartile }\end{array}$ & mean & $\begin{array}{l}\text { 3rd } \\
\text { quartile }\end{array}$ \\
\hline \multirow[t]{2}{*}{ Import Demand } & \multicolumn{3}{|c|}{1.57} & \multicolumn{3}{|c|}{2.32} \\
\hline & 1.31 & & 1.77 & 1.96 & & 2.72 \\
\hline \multirow[t]{2}{*}{ REER(lag) } & \multicolumn{3}{|c|}{-0.04} & \multicolumn{3}{|c|}{-0.04} \\
\hline & -0.13 & & 0.10 & -0.17 & & 0.13 \\
\hline \multirow[t]{2}{*}{ REER } & \multicolumn{3}{|c|}{-0.02} & \multicolumn{3}{|c|}{-0.02} \\
\hline & -0.14 & & 0.13 & -0.23 & & 0.21 \\
\hline \multirow[t]{2}{*}{ constant } & \multicolumn{3}{|c|}{0.01} & \multicolumn{3}{|c|}{0.00} \\
\hline & 0.00 & & 0.02 & -0.01 & & 0.02 \\
\hline \multirow[t]{2}{*}{ R squared } & \multicolumn{3}{|c|}{0.82} & \multicolumn{3}{|c|}{0.72} \\
\hline & 0.77 & & 0.89 & 0.64 & & 0.85 \\
\hline
\end{tabular}

Note: The table reports (simple) averages as well as interquartile ranges of import demand elasticities calculated for each country separately. Import demand is measured as IAD in column 1 and with GDP in column2. The analysis uses quarterly data from 1995Q1 to 2015Q4. Import Demand variable is statistically significant at 1\% in each country, while the other explanatory variables are statistically significant only in some countries.

Table 4: Country-by-country regressions' estimation results

\begin{tabular}{|c|c|c|c|c|}
\hline & \multicolumn{2}{|c|}{ Emerging \& developing economies } & \multicolumn{2}{|c|}{ Advanced economies } \\
\hline & GDP specification & IAD specification & GDP specification & IAD specification \\
\hline Import Demand & 2.27 & 1.49 & 2.35 & 1.60 \\
\hline REER & -0.11 & -0.09 & 0.02 & 0.01 \\
\hline Import Demand (lag) & -0.05 & 0.09 & 0.24 & 0.17 \\
\hline REER(lag) & -0.07 & -0.07 & -0.03 & -0.03 \\
\hline R squared & 0.66 & 0.78 & 0.75 & 0.85 \\
\hline
\end{tabular}

Note: The table reports (simple) averages of import demand elasticities calculated for each country separately. Import demand is measured as import-intensity adjusted demand in column 2 and 4 and with GDP in column 1 and 3. The analysis uses quarterly data. Import Demand variable is statistically significant at $1 \%$ in each country, while the other explanatory variables are not always statistically significant, depending on the countries.

Netherland, Portugal, Slovak Republic, Slovenia, Spain, Sweden, UK, Australia, Canada, Japan, South Korea, and the United States) and 12 emerging and developing economies (China, Brazil, Russian Federation, India, Bulgaria, Cyprus, Hungary, Indonesia, Mexico, Poland, Romania, Turkey). 
Figure 9 shows the weighted average of predicted import growth coming from country-by-country regressions. The results are very similar to Figure 7, but the shortfall in real import growth relative to the predicted value, from 2012 onwards, is even smaller.

Over the entire sample period, 1995Q1-2015Q4, the unpredicted real import growth is on average 0.8 percentage points for model using IAD against 1.1 percentage points when using GDP. The model using IAD country-by-country predicts on average $86 \%$ of the changes in import of goods and services during the period 1995Q1-2015Q4, compared to $80 \%$ explained by the model using GDP.

Figure 9: Actual and predicted evolution of real goods and services import growth: full sample

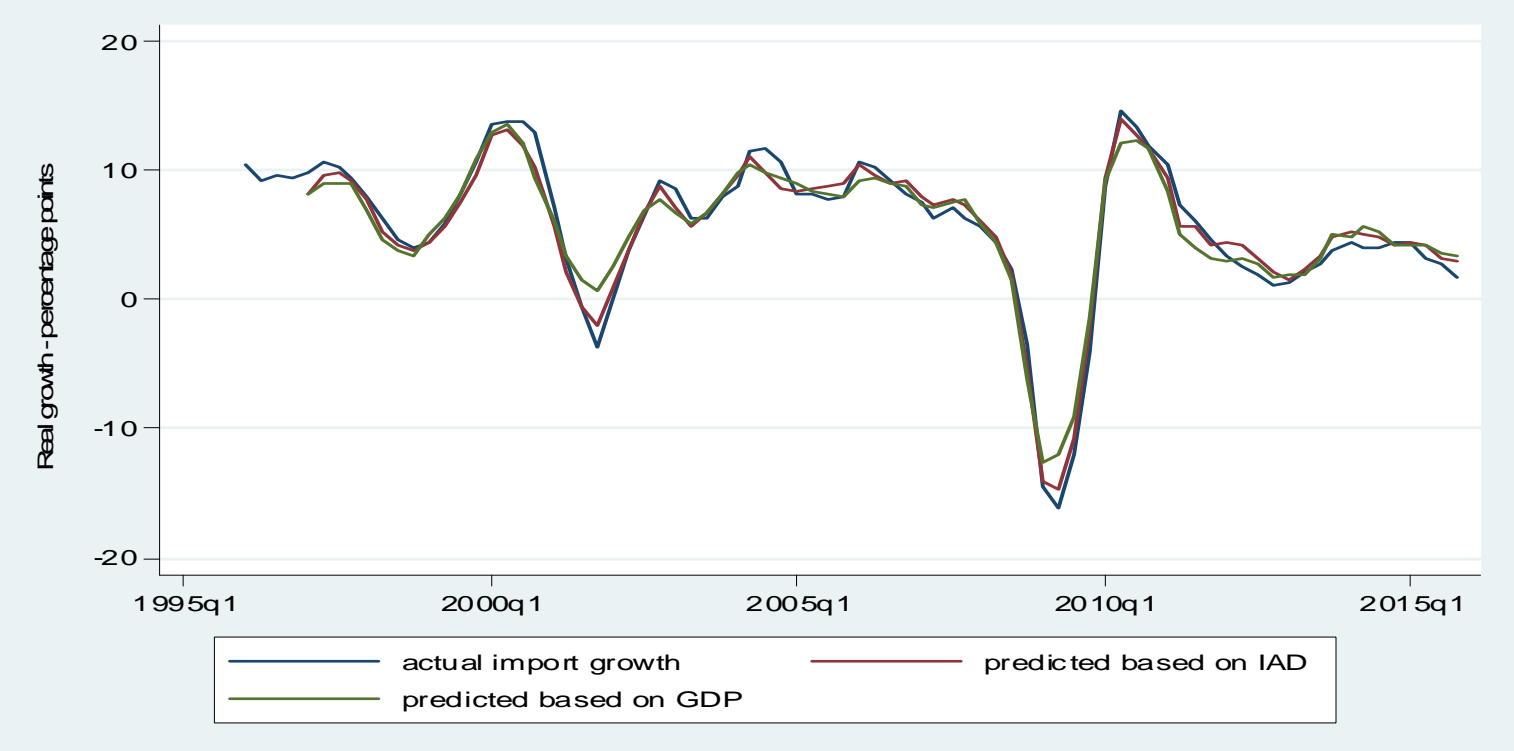

Note: The fitted values are based on country-by-country regressions, using IAD or GDP as measure of demand.

The superiority of the IAD against GDP in tracking real import growth is clear from Figure 7, 9 and 10; backward projections for real import growth based on the IAD measure are closer to actual values than projections based on GDP. This is true before, during and after the great trade collapse. Although the difference between the two projections is modest overall, Figure 10 shows that IAD-based projections perform better than GDP projections especially for developing and emerging economies, which have been the driver of the trade slowdown from 2012 onwards. 
Figure 10: Actual and predicted evolution of real goods and services import growth: advanced vs developing and emerging economies

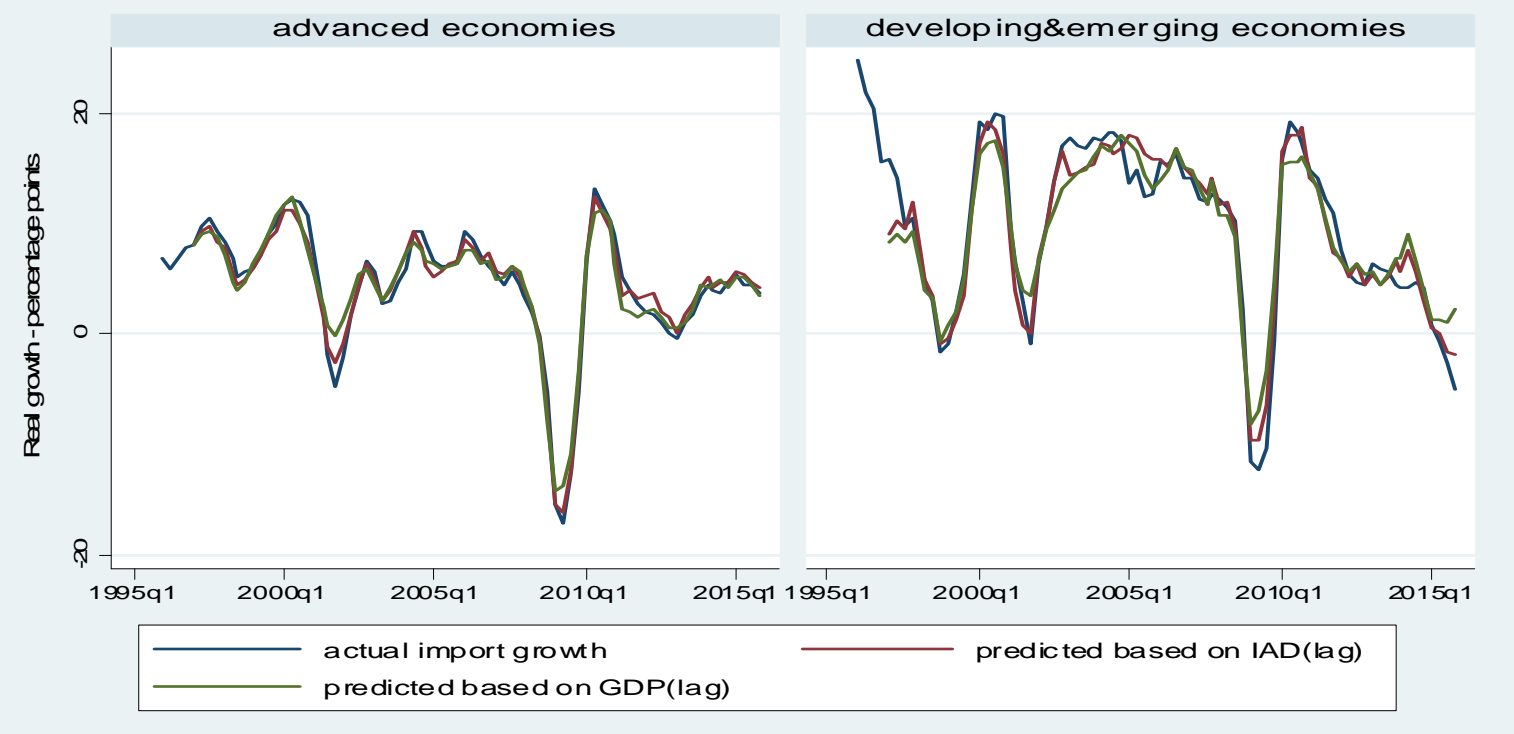

Note: Actual and predicted aggregate year-on-year import growth is calculated as the weighted average of country-specific real import growth rates, where nominal import shares are the weights used. The fitted value are based on country-by-country regression (equation 5), using IAD or GDP as measure of demand.

The better performance of IAD relative to other proxies for aggregate demand confirms the role of trade-intensive components in explaining the shifts in trade growth. The relative importance of the various components of aggregate demand is explained below.

\section{IV.2 Explaining the trade slowdown in the recent period by demand components}

We broke the sample period into two sub-periods, before and after the financial crisis (1995-2007 and 2012-2015), to evaluate which determinant (including within IAD) explains the trade slowdown. We estimated for each country the import growth predicted by each component of IAD, based on the coefficients of the country-by-country regressions performed according to equation (5). We averaged it for the overall economy, to obtain the import growth predicted, globally, by each component of IAD, throughout the time series. By doing this, we thus were able to compare different periods of time, and in these periods, the way in which each IAD component had influenced import growth. The methodology for the calculation of these contributions is explained in Box 1. Of particular interest is to compare the pre- financial crisis period, one of relatively higher trade growth, to the post-financial crisis period (Table 5), while "neutralizing" the crisis period per se, to single out the contributing factors to the post-crisis trade slowdown. 
Table 5: The decline in weighted average real import growth across countries (percentage points)

\begin{tabular}{lccc}
\hline \hline & $1995-2007$ & $2012-2015$ & $2012-2015$ minus \\
goods and services & 7.9 & 3.0 & -4.9 \\
Total & 6.4 & 2.9 & -3.5 \\
Advanced Economies & 12.7 & 3.4 & -9.2 \\
Developing and Emerging Economies & & & \\
\hline \hline
\end{tabular}

Source: OECD and authors' calculation.

Note: Individual economies' real import year-on-year growth rates are aggregated using the average nominal import share between 2005 and 2014 as weight. The sample includes our 38 countries.

The outcome of this exercise is summarized in Table 6: first, on average $80 \%$ of the difference in global import growth between 2012-2015 and 1995-2007 is attributable to IAD. It actually peaks to $94.4 \%$ for advanced economies, while accounting for $62.5 \%$ of the difference for developing and emerging economies.

Table 6: Individual contribution of IAD components in real import growth slowdown

\begin{tabular}{lc|cccc|cc}
\hline & \multicolumn{7}{c}{ Percentage of real trade slowdown explained by: } \\
\cline { 2 - 7 } & IAD & C & G & I & X & $\begin{array}{c}\text { Direct } \\
\text { IAD }\end{array}$ & $\begin{array}{c}\text { Indirect } \\
\text { IAD }\end{array}$ \\
\hline & & & & & & & \\
Total & 80.1 & 14.3 & 5.7 & 27.6 & 32.5 & 31.2 & 46.2 \\
Advanced Economies & 94.4 & 19.4 & 8.8 & 27.7 & 38.5 & 13.6 & 78.8 \\
$\begin{array}{l}\text { Developing and Emerging } \\
\text { Economies }\end{array}$ & 62.5 & 8.0 & 1.8 & 27.5 & 25.2 & 52.8 & 6.5 \\
\hline \hline
\end{tabular}

Source: Authors' calculations based on country-by-country regressions of equation (5).

In Figure 11, we have added to IAD the other significant explanatory variable, i.e. the real effective exchange rate (REER). Given that, for developed economies, IAD explains 94\% of the 2012-2015 trade slow-down relative to pre-crisis, the REER does not come up in Figure 11 as an important contributor for advanced economies. However, overall REER is contributing $12 \%$ to the trade slowdown, mainly as a result of its contribution to developing and emerging economies (the depreciation of their REER seemed to have slowed real import growth). ${ }^{11}$

${ }^{11}$ In China, India, Bulgaria, Cyprus, Hungary, Indonesia however, coefficient estimates on real effective exchange rate are counterintuitive: the estimates are negative or not statistically significant. These counterintuitive findings are already reported in the literature. For instance in the case of China, many papers already highlight the ambiguous net effect of an RMB appreciation on China's price competitiveness, because of the opposite effect on the value added component of Chinese exports and imported intermediate input costs (Cheung, Chinn and Qian (2012); Devereux and Genberg (2007)). For European countries Giordano and Zollino (2016) and Christodoulopoulu and Tkacevs (2014) found a negative effect of a real appreciation on imports, possibly because the real appreciation make exports more expensive and the country get disengaged from the global value chain with a corresponding decline in imports. 
Looking back at Table 6 , in the $80 \%$ of the trade slowdown explained by IAD, for the average economy the decline in the growth of investment and exports account for most of the trade slowdown (60\%), the two most trade-intensive elements of demand. While in developing and emerging economies private consumption plays only a minor role in the trade slowdown, in developed countries consumption has a higher contributing power (19.4\%). A look at Figure 3 highlights the growing import-intensity of consumption, a mark of globalization.

Table 6 also allocates the import growth slowdown between direct and indirect imports, according to the methodology developed by Bussière et al. (2013) and explained in Box 2. On average indirect IAD alone explains around $46.2 \%$ of the trade slowdown, whereas the contribution of direct IAD is much smaller. This finding highlights the role of intermediate inputs in explaining the slowdown, in particular in developed countries.

Figure 11: Decomposing the slowdown in real import growth

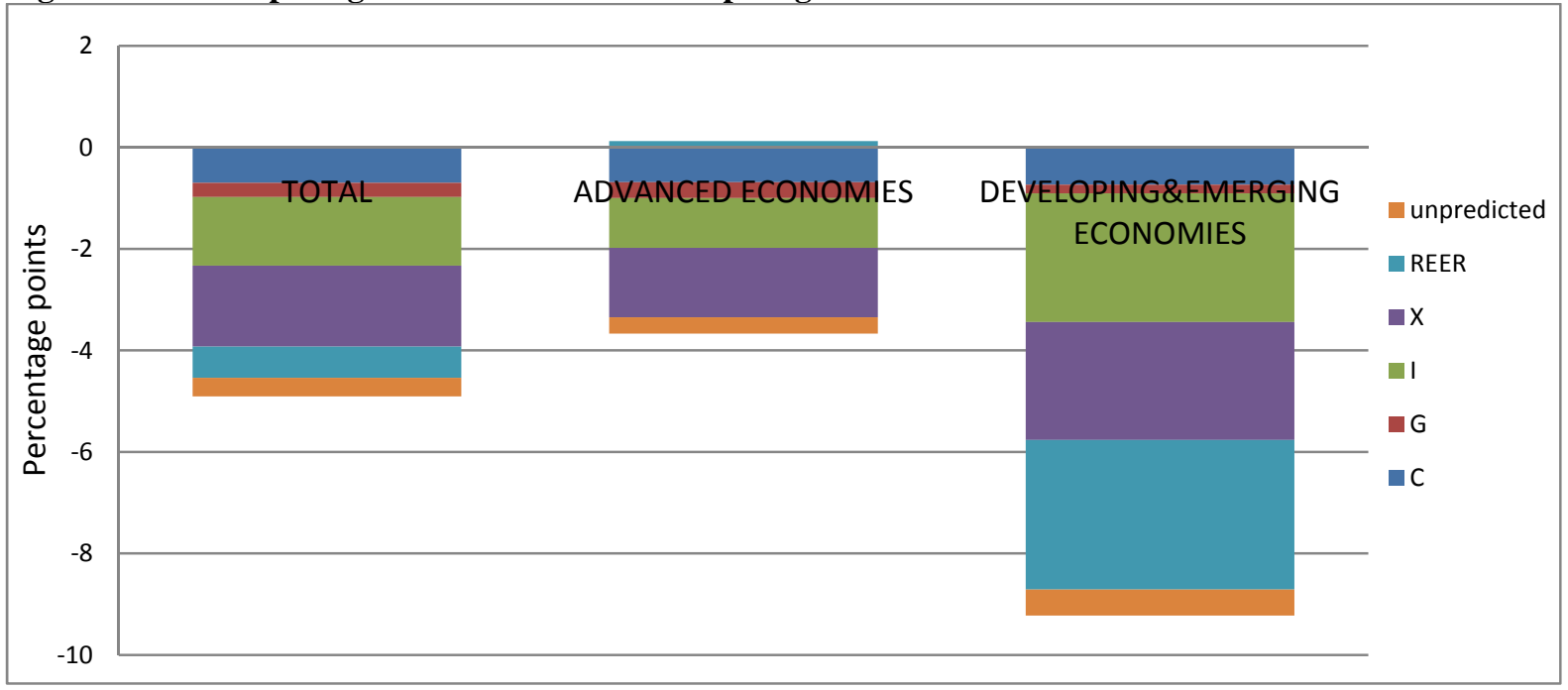

Source: Authors' calculations.

Note: We decomposed the difference between average real import growth between 1995-2007 and 2012-2015 into proportions predicted by private consumption, government consumption, investment, exports, REER and unpredicted part.

Gross fixed investment has the highest import content among the components of aggregate demand, as indicated in section III. It has been weak in the advanced countries since the end of the financial crisis - it is actually the only component of aggregate demand which has still not fully recovered from its pre-crisis levels, as shown in Figure 12. 
Figure 12: Investment to GDP ratio: advanced versus emerging and developing countries

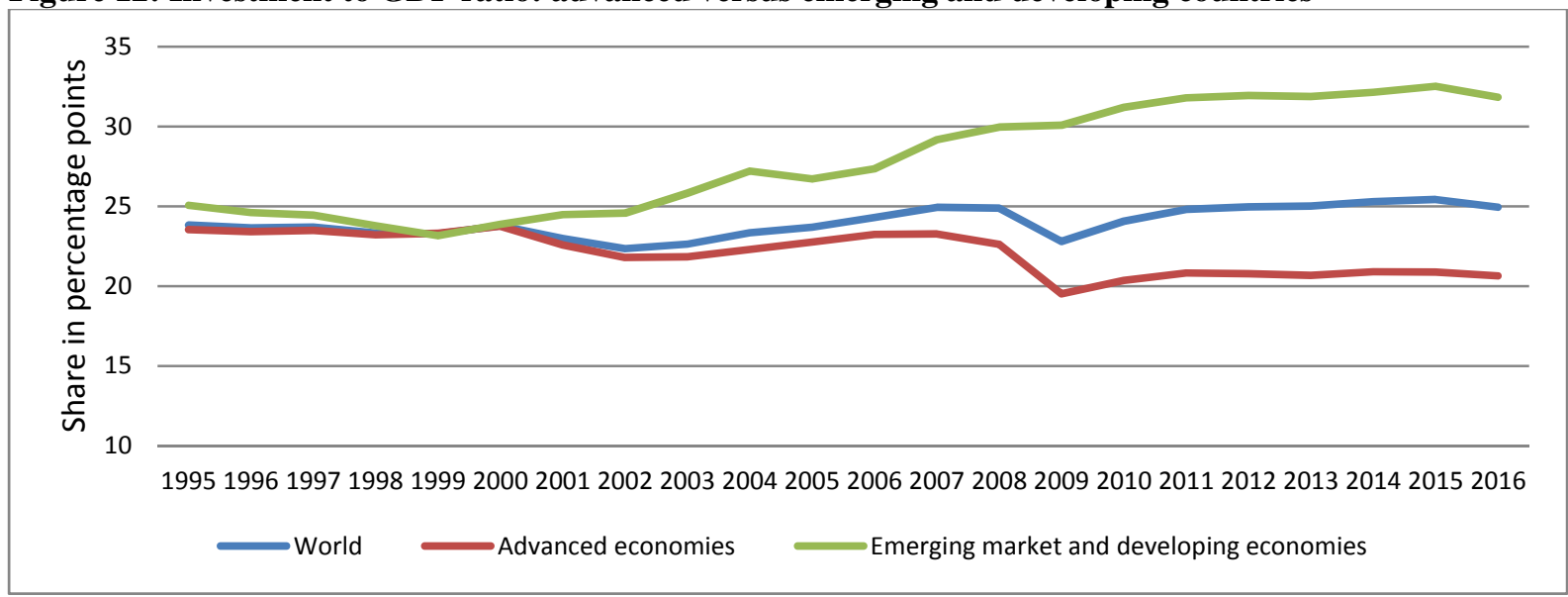

Source: IMF (World Economic Outlook 2016).

Note: Country-level data are weighted by GDP valued at purchasing power parities (PPPs) as a share of group GDP.

Gross fixed investment in emerging and developing countries has been more resilient in the immediate aftermath of the financial crisis, though. It continued to increase strongly until 2012, thus stagnated in 2013-2014, before falling as a share of GDP in these countries (particularly corporate investment) (Figure 12). In the specific cases of China and Russia, though, the share of investment in GDP has been declining for a longer period, contrary to other elements of demand such as government expenditure or consumption, thereby clearly driving down import growth in these countries.

\section{IV.3 Distinguishing goods and services}

We distinguished trade in goods from trade in services, since the latter proved to be less volatile and cyclical than the earlier (ECB, 2016). Costantinescu et al. (2015) had found that one of the main forces behind the decline of the world trade elasticity has been the fall of the goods trade's elasticity. The distinction between real imports of goods and services indicates that services have been more resilient than goods during 2012-2015, compared to the earlier period (1995-2007). Services and goods' trade volume grew at an average annual rate of 6.2 and 6.8 per cent respectively between 1995 and 2007. During 2012-2015, services trade fell to an average annual growth rate of 5 per cent while it dropped to 2 per cent for goods.

Table 7: The decline in weighted average real import growth (goods versus services) across countries (percentage points)

\begin{tabular}{lccc}
\hline & $1995-2007$ & $2012-2015$ & $\begin{array}{c}2012-2015 \text { minus } \\
1995-2007\end{array}$ \\
\hline Goods & & & -4.8 \\
Total & 6.8 & 2.0 & -3.4 \\
Advanced Economies & 5.3 & 1.9 & -9.1 \\
Developing and Emerging Economies & 11.4 & 2.2 &
\end{tabular}




\begin{tabular}{lllc}
\hline Total & 6.2 & 5.0 & -1.2 \\
Advanced Economies & 5.8 & 3.7 & -2.1 \\
Developing and Emerging Economies & 7.3 & 9.1 & 1.9 \\
\hline \hline
\end{tabular}

Source: World Bank (WDI), WTO Statistics database and authors' calculation

Note: Individual economies' real import growth rates are aggregated using the average nominal import share between 2005 and 2014 as weight. The sample includes our 38 countries

\section{NON-DEMAND DRIVEN TRADE SLOWDOWN}

Since weak economic activity and changes in the composition of demand cannot predict $100 \%$ of the observed weakness in trade since 2012, section V looks at the role of non-demand related factors highlighted in the literature, still by comparing the two periods of our sample, 1995-2007 and 2012-2015. We have incorporated proxies for protectionism (V.1) and global value chains (GVCs) (V.2) in our main model. ${ }^{12}$ While the explanatory power of IAD did not change significantly, only GVCs come up as statistically significant. ${ }^{13}$

\section{V.1 Dealing with protectionism}

The IMF (2016), OECD (2016), and ECB (2016) considered, in different ways, the role of increased protectionism or deceleration in trade liberalization in the years following the financial crisis. Measures of protectionism do not come up significantly and meaningfully (i.e. with large coefficients) in the IMF and ECB work, while it bears greater impact in the OECD work.

The IMF combined a mix of databases for the measurement of protectionist measures, such as the World Bank's Temporary Trade Barriers Database, the tariffs contained in the World Trade Organization Tariff Database, and WTO Regional Trade Agreements Database for the stock of free trade agreements. ${ }^{14}$ Working at product-level the IMF found that all these variables were statistically significant with the expected sign, with a very small contribution to the trade slowdown (less than 5\%). The OECD found, at the global level a bigger impact by using a measure of trade regulation and tariffs from the Fraser Institute, comprising four components (tariffs and non-tariffs barriers, capital controls and exchange rates controls). Evenett and Fritz (2015) showed that protectionist non-tariff measures have increased in recent years and that the product categories that have seen the largest trade decline are those facing the largest number of trade restrictions. While accounting for some increase in protectionism (notably by using the Global Trade Alert Database for non-tariff measures and World Development Indicators Database for tariffs), the ECB does not attribute to protectionism a strong explanatory role.

\footnotetext{
${ }^{12}$ Measures of protectionism and GVC participation are only available at annual level; therefore we converted annual figures into quarterly figures in order to obtain results comparable with those in section IV.

${ }^{13}$ This estimate is likely to be a lower bound on the actual contribution of those factors to the weak trade growth since trade costs play a big role in shaping global value chains, productivity and economic growth and ultimately import demand.

${ }^{14}$ The Temporary Trade Barriers Database includes only the national governments' use of three policies: antidumping, global safeguards and countervailing duties (Bown, 2016).
} 
In our study, we have introduced, alternatively, in Equation (5), measures of protectionism used by previous work, be it the freedom to trade internationally index by the Fraser Institute, the tariffs contained in the World Development Indicators Database, and the World Bank's Temporary Trade Barriers Database. We find that, in our main specification, none of these measures of protectionism are statistically significant, while coefficients for other main variable remain stable and significant (see Table 8).

Table 8: Real import growth and protectionism

\begin{tabular}{|c|c|c|c|c|}
\hline VARIABLES & $\begin{array}{l}\text { (1) } \\
\text { actual real import } \\
\text { growth }\end{array}$ & $\begin{array}{l}\text { (2) } \\
\text { actual real import } \\
\text { growth }\end{array}$ & $\begin{array}{l}\text { (3) } \\
\text { actual real import } \\
\text { growth }\end{array}$ & $\begin{array}{l}(4) \\
\text { actual real import } \\
\text { growth }\end{array}$ \\
\hline Import Demand & $\begin{array}{l}1.501 * * * \\
(0.0558)\end{array}$ & $\begin{array}{l}1.473 * * * \\
(0.0473)\end{array}$ & $\begin{array}{l}1.503 * * * \\
(0.0570)\end{array}$ & $\begin{array}{l}1.503 * * * \\
(0.0568)\end{array}$ \\
\hline REER (lagged) & $\begin{array}{c}0.0810^{* * *} \\
(0.0283)\end{array}$ & $\begin{array}{c}0.0623^{* *} \\
(0.0289)\end{array}$ & $\begin{array}{c}0.0811^{* * *} \\
(0.0282)\end{array}$ & $\begin{array}{c}0.0808 * * * \\
(0.0283)\end{array}$ \\
\hline $\begin{array}{l}\text { Freedom to trade } \\
\text { internationally (Fraser } \\
\text { Institute Index) }\end{array}$ & $\begin{array}{c}0.0436 \\
(0.0524)\end{array}$ & & & \\
\hline Temporary Trade Barriers & & $\begin{array}{l}-0.000217 \\
(0.00441)\end{array}$ & & \\
\hline tariff & & & $\begin{array}{c}-0.00375 \\
(0.00846)\end{array}$ & \\
\hline Constant & $\begin{array}{c}0.00977 * * * \\
(0.00348)\end{array}$ & $\begin{array}{c}0.0121^{* * *} \\
(0.00285)\end{array}$ & $\begin{array}{c}0.00969 * * * \\
(0.00341)\end{array}$ & $\begin{array}{c}0.00981^{* * *} \\
(0.00345)\end{array}$ \\
\hline Observations & 2,859 & 2,783 & 2,859 & 2,859 \\
\hline R-squared & 0.704 & 0.712 & 0.704 & 0.704 \\
\hline Number of countries & 38 & 37 & 38 & 38 \\
\hline
\end{tabular}

Note: The table shows estimates of panel regression, as described in Equation 5, using quarterly data. To save space we did not report the point estimates of the lagged value of the dependent variable and import demand as well as REER at time t. Column 4 represents the baseline specification. For Temporary Trade Barriers variables we do not have data for Russia, so we excluded the country from the analysis. Robust standard errors in parentheses *** $\mathrm{p}<0.01, * * \mathrm{p}<0.05, * \mathrm{p}<0.1$

Our findings suggest that protectionist trade policies, as measured by our three variables, play a statistically non-significant, if not negligible role in explaining the recent trade slowdown. However, it is important to keep in mind that these proxies for protectionism may not cover all existing measures of protectionism. It is also possible that the slower pace of trade liberalization in the 2000s relative to the long 1990s, rather than an increase in protection, contributes to explain the declining responsiveness of world trade to GDP. 


\section{V.2 Dealing with global value chains}

Some have argued that the expansion of GVCs has come to an end, because protectionism had risen, producers had exhausted efficiency gains, and/or wage-toproductivity gaps had closed up. However, the impact of GVCs on the recent trade slowdown is difficult to measure in part because of large delay in data availability (notably in the construction of the GVC participation index). ${ }^{15}$

Constantinescu, Mattoo and Ruta (2015) highlighted the role of a lesser expansion in global value chains showing the closing gap between the long-run elasticities of value added trade with respect to income and the (gross) trade elasticities since 2000s. The IMF (2016) constructed a GVCs participation measure using Eora input-output tables. The authors found that a $10 \%$ increase in participation in GVCs was associated with a $1 \%$ increase in real import growth. The ECB (2016) also found that changes in GVC participation had played a role in the fluctuations in the global trade-income elasticity, raising the elasticity by 0.3 in the 2000s. However, ECB authors did not find that GVCs had contributed to the lower elasticity since the Great Recession. The OECD (2016) used an alternative indicator of countries' backward participation in value chains, i.e. the ratio of intermediate goods imports to final domestic demand (adjusted to remove strong influences from commodity prices and business cycle fluctuations), to make up for the unavailability of recent TiVa data. Their analysis is the one, among the abovementioned literature, providing the largest role to GVCs in explaining the slowdown in world trade.

We have constructed a measure of global value chain participation using trade data from WIOD. This measure of GVCs participation index, consider two dimensions of value chain participation: a country's use of imported goods and services to produce its exports (backward participation) and a country's exports of intermediate goods and services that are processed by the trading partner and re-exported (forward participation) (see Box 3 for an explanation on the construction of GVC participation index). As shown in Figure 13, participation in GVCs for the 38 countries analysed in this paper increased steadily between 1995 and 2008, but since 2011 this has levelled off and even declined in 2014, indicating that global supply chains have expanded at a slower pace.

15 The TiVA database for example is only available until 2011. 


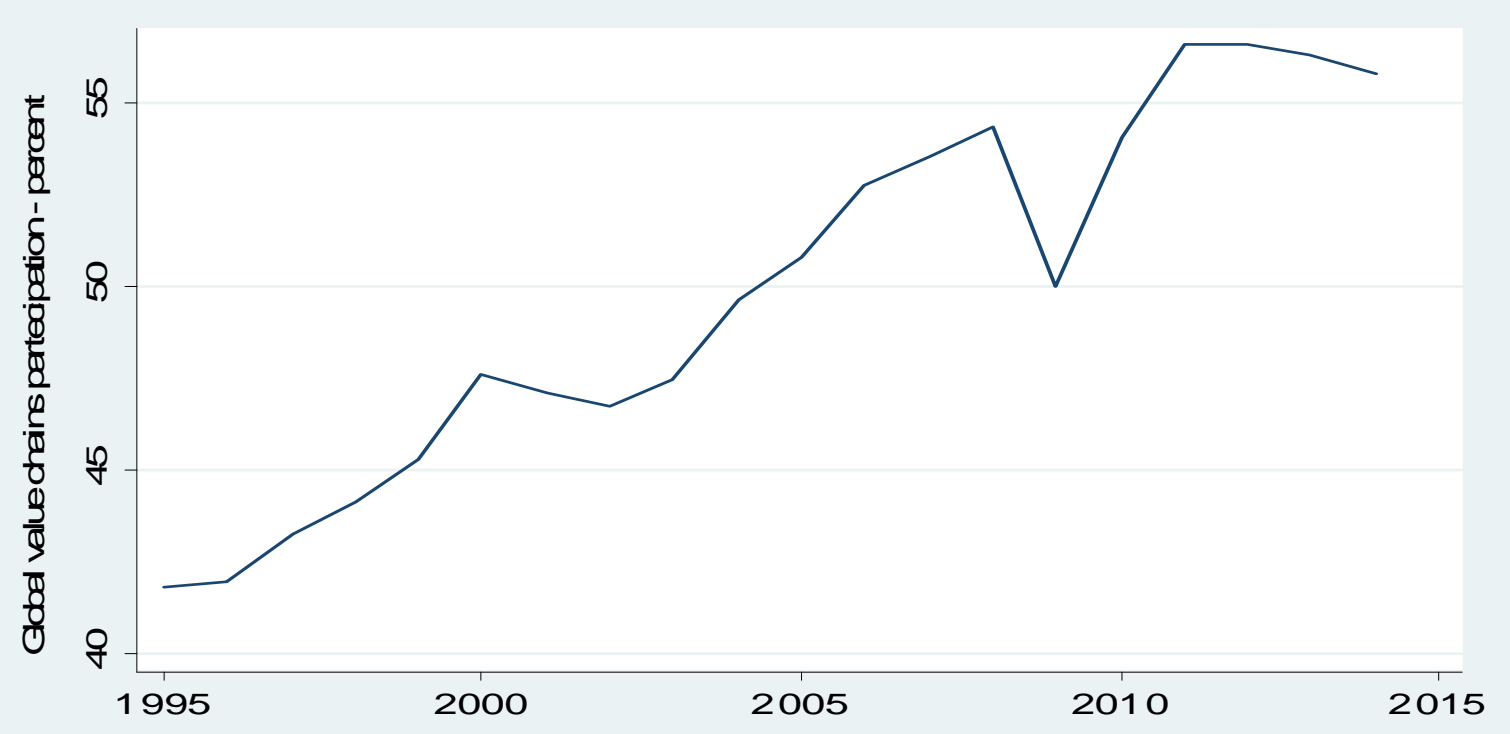

Source: WIOD and authors' calculations.

Note: The graph averages GVC participation for the 38 countries analysed in this paper.

We have introduced in Equation (5) the measure of participation in GVCs, which is found positive and statistically significant in both panel and country-by-country regressions, suggesting that the slower pace of global value chain participation is associated with lower real import growth (Table 1 in Box 3). This measure of GVCs participation is statistically robust. Introducing it in Equation (5) leads to a small reduction of IAD's elasticity of imports (from 1.5 to 1.3) and REER, but to a limited extent. In order to find the share of the real import growth' slowdown to be attributed to GVCs, we used country-specific residuals, which are the difference between the actual and model predicted real import growth. We have regressed these residuals against the growth in GVC participation by country. The resulting elasticity, for each country, is thus multiplied by the GVC slowdown in the period 2012-2015 relative to 1995-2007. Such multiplication provides the share of the unpredicted import slowdown which can be attributed to GVCs.

We found that around 65\% of the slowdown in import growth not accounted for by IAD and REER can be explained by the slowdown in GVC participation. Since according to Table 1, Box 3, over $70 \%$ (instead of $80 \%$ ) of the recent import slowdown is explained by IAD and $10 \%$ (instead of $12 \%$ ) by REER, it would imply that $65 \%$ of the remaining $20 \%$ unexplained (some 13\%) would be explained by GVCs.

This exercise shows that a big share of the trade slowdown not accounted for by weak economic activity and its composition is attributable to the slowing expansion of global value chains. Overall, though, GVC participation accounts for less than $1 / 5^{\text {th }}$ of IAD's explanatory power.

\section{OTHER ROBUSTNESS CHECKS}

\section{VI.1 Statistical robustness}


We conducted a wide range of robustness and sensitivity analyses on our equations, some of them being directly run with regressions, as for example in footnote 9 and 10 (Section IV.1). These tests confirmed that our results were robust to various alterations to our baseline models (unit root tests, correcting for heteroskedacity and autocorrelation, etc).

For example, we re-estimated the main model using a different specification, whereby real import growth depended only on the contemporaneous growth rate of the same explanatory variables. Our findings are robust to this specification.

Thus we added a crisis dummy (value 1) to the Equation 5, to take account of the financial crisis period (2008-2010). The crisis dummy was found statistically significant for some countries, but overall adding this variable did not change our main results.

Our regression results proved to be very stable for different model specifications and coefficients for main explanatory variables are statistically significant, suggesting that multicollinearity may not be a concern. However, as an additional check, we calculated the variance inflation factor (VIF) for each of the country-by-country regressions. For all countries VIFs are lower than 10, which is the standard cut-off for further investigation.

\section{VI.2 Dealing with exports at global level}

One country can take the external demand and hence exports as given, but for the world, only the sum of domestic demand determinates import growth. In order to investigate how much of the global trade slowdown is driven by domestic demand (i.e. each country domestic demand and the domestic demand of its trading partners), we estimated an alternative import demand equation relative to Equation (5) estimated in section IV. In this model, absorption is proxied by domestic IAD (DIAD) and exports predicted by trading partners' domestic IAD (see Box 4 for further details). The DIAD is constructed in the same way as the IAD, but focusing only on the domestic components of aggregate demand, i.e. excluding the exports.

Figure 14: Decomposing the slowdown in real import growth

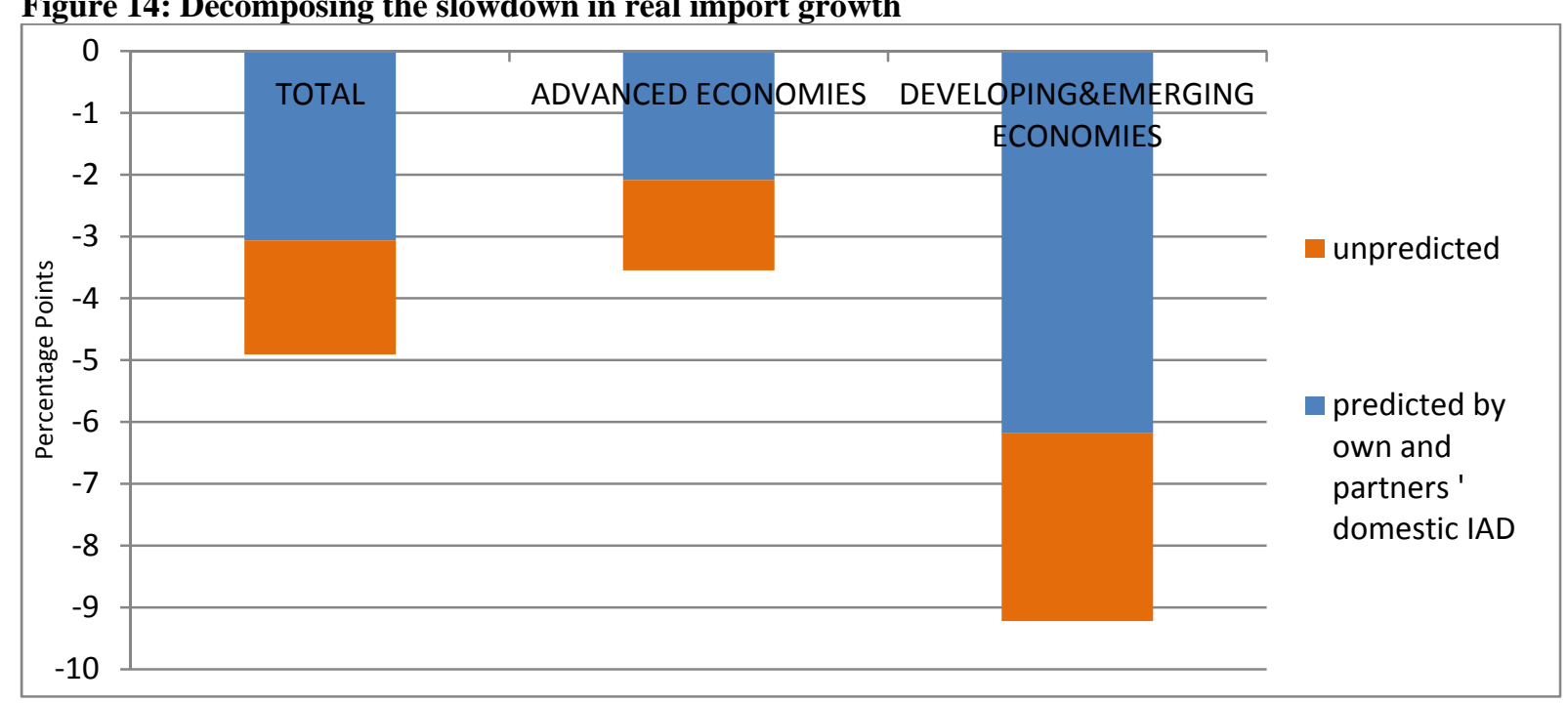

Source: Authors' calculations. 
Figure 14 shows the decomposition of the difference between average real import growth between 1995-2007 and 2012-2015 into domestic demand, external demand predicted by trading partners' domestic demand and unpredicted part. When excluding exports and relying on the concept of domestic import intensity adjusted demand, the model's predictive power falls a bit, to $63 \%$ of the actual trade slowdown overall. This is mainly a result of lower predictive power of developed economies. For developing economies, the model's prediction power remains close to $70 \%$. One must acknowledge though, that the exclusion of exports is a bit of an extreme test since the initial sample of countries account for $76 \%$ of trade only. Hence for such a panel of countries total exports would not equal total imports, therefore not fully satisfying the exclusion of exports.

\section{CONCLUSION}

This paper provided reasonable albeit robust evidence that the use of non-trade weighted GDP, as a proxy for income, was no longer the best measure of the income elasticity of trade and led to forecasting errors in determining global trade trends. Instead, we estimated the standard global import equation over the period 1995-2015, using an import intensity-adjusted measure of aggregate demand (IAD), calculated from input-output tables at country level, and compared results with regressions using GDP. We find a lower and less volatile, long-term elasticity of imports to demand (1.5 instead of 2 for GDP); besides, the integration of IAD into the standard global import equation helps predict $76 \%$ to $86 \%$ of the changes in values of global imports, a better performance than if using GDP. The use of IAD also enabled us to measure the relative importance of each component of demand, according to their trade intensity. The model is able to account for over $90 \%$ of the recent trade slowdown (2012-2015), with IAD alone explaining $80 \%$ of it. The composition of demand is the primary explanation of the trade slowdown because the most trade-intensive components were the ones slowing down the most (such as investment). The slowdown in global value chains explains more than half of the remaining share of the global trade slowdown, not explained by demand factors. Protectionism does not come up as statistically significant.

In the future, though, such analyses are likely to benefit from current efforts to improve world input-output databases. We were able to rely on data covering 38 countries accounting for $76 \%$ of global imports. Hopefully, the WIOD or similar databases will help getting closer to $100 \%$ of global trade, a difficult task though. Another challenge would be on the aggregate demand side, as all countries in the world do not have expenditure-based data on a monthly or even basis. Improved measurement, at the aggregate levels, of "vertical specialisation" and protectionism might actually allow for better consideration of their respective role in the global trade slowdown. Finally, the importance of financial factors, e.g. the contraction of cross-border financial flows (foreign direct investment, trade finance) might be tested as explanatory variables, but measurements of such flows are still subject to significant data gaps. 


\section{APPENDIX}

Box1: Calculating the contribution of aggregate demand components' in trade slowdown

Using the estimated coefficients from regression (5), we calculated the contribution of each of the aggregate demand components and that of the real effective exchange rates in the real import slowdown. We also performed this decomposition separately for advanced as well as emerging and developing economies, in order to highlight possible differences (Figure 10).

The import slowdown decomposition requires a few steps. First, for each country (c) and year ( $\mathrm{t}$ ), we computed the import growth predicted by each demand component $\mathrm{k}$ $\left(\Delta \ln \widehat{M}_{\mathbf{c}, \mathbf{t}}^{\mathbf{k}}\right)$ as follow:

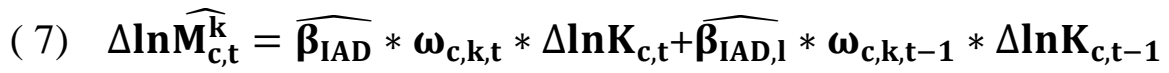

Where:

$\mathrm{k}=\mathrm{C}, \mathrm{G}, \mathrm{X}, \mathrm{I}$

$\widehat{\beta_{\mathrm{IAD}}}$ and $\widehat{\beta_{\mathrm{IAD}, 1}}$ are the estimated coefficients of equation (5)

Similarly, we computed the import growth predicted by REER as follows:

$$
\Delta \ln \widehat{\mathbf{M}_{c, t}^{\mathrm{REER}}}=\widehat{\beta_{\mathrm{REER}}} * \Delta \ln \mathrm{REER}_{\mathrm{c}, \mathrm{t}}+\widehat{\boldsymbol{\beta}_{\mathrm{REER}, \mathrm{l}}} * \Delta \ln \mathrm{REER}_{\mathrm{c}, \mathrm{t}-1}
$$

Secondly, taking the weighted average of the import growth predicted by each demand component $\mathrm{k}$ across countries and then between 1995-2007 and 2012-2015, we get the import growth for the average economy predicted by each demand component $\mathrm{k}$, in 19952007 (i.e. $\Delta \ln _{\mathrm{M}_{12-15}^{\mathrm{k}}}$ ) and in 2012-2015 (i. e. $\Delta \ln \widehat{\mathrm{M}_{95-07}^{\mathrm{k}}}$ ). In a similar way we get the import growth for the average economy predicted by REER in 1995-2007 (i.e. $\Delta \ln \mathrm{M}_{95-07}^{\mathrm{REER}}$ ) and 2012-2015 (i.e. $\Delta \ln \widehat{M_{12-15}^{R E R}}$ ). Finally, dividing the predicted slowdown in real import growth from each demand component $\mathrm{k}$ by the actual slowdown in real import growth we get the contribution of each aggregate demand component $\mathrm{k}$ in the real import slowdown, $\gamma_{\mathrm{k}}$, for the average economy:

(9) $\gamma_{k}=\frac{\Delta \ln M_{12-15}^{\bar{k}}-\Delta \ln M_{95-07}^{\bar{k}}}{\Delta \ln M_{12-15}-\Delta \ln M_{95-07}}$

The percentage of import slowdown explained by the REER, $\gamma_{\text {REER }}$, is computed in a similar way:

(10) $\boldsymbol{\gamma}_{\mathrm{REER}}=\frac{\Delta \ln \mathbf{M}_{12-15}^{\widehat{\mathrm{REER}}}-\Delta \ln \mathbf{M}_{95-07}^{\widehat{\mathrm{REER}}}}{\Delta \ln \mathbf{M}_{12-15}-\Delta \ln \mathbf{M}_{95-07}}$

Source: Bussiere et al. (2013) 
Box2: Calculating the contribution of direct and indirect IAD in trade slowdown

First, for each country (c) and year (t), we computed the year-on-year direct (11) and indirect (12) IAD growth:

$$
\begin{aligned}
& \ln I A D_{t}^{d i r}=\omega_{C, t}^{d i r} * \ln C_{t}+\omega_{G, t}^{d i r} * \ln G_{t}+\omega_{I, t}^{d i r} * \ln I_{t}+\omega_{X, t}^{d i r} * \ln X_{t} \\
& \ln I A D_{t}^{\text {indir }}=\omega_{C, t}^{\text {indir }} * \ln C_{t}+\omega_{G, t}^{\text {indir }} * \ln G_{t}+\omega_{I, t}^{\text {indir }} * \ln I_{t}+\omega_{X, t}^{\text {indir }} * \ln X_{t}
\end{aligned}
$$

We computed the import growth predicted by direct IAD $\left(\Delta \mathbf{\operatorname { l n }} \widehat{\mathbf{M}_{\mathbf{c}, \mathbf{t}}^{\text {IADd }} \mathbf{r}}\right)$ as follow:

$$
\Delta \ln \mathbf{M}_{\mathrm{c}, \mathrm{t}}^{\widehat{\mathrm{IAD}} \mathrm{II}}=\widehat{\beta_{\mathrm{IAD}}} * \Delta \ln I A D_{t}^{d i r}+\widehat{\beta_{\mathrm{IAD}, \mathrm{I}}} * \Delta \ln I A D_{t-1}^{d i r}
$$

Where:

$\widehat{\beta_{I A D}}$ and $\widehat{\beta_{I A D}, 1}$ are the estimated coefficients of equation (5)

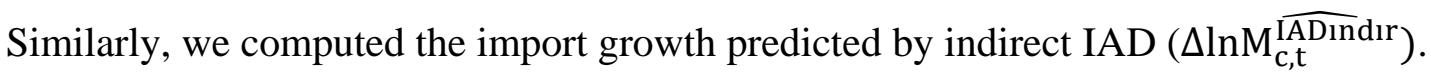

Secondly, taking the weighted average of the import growth predicted by direct IAD across countries and then between 1995-2007 and 2012-2015, we get the import growth for the average economy predicted by direct IAD, in 1995-2007 (i.e. $\Delta \ln \mathrm{M}_{12-15}^{\widehat{\mathrm{IAD}, \mathrm{d}} \mathrm{rr}}$ ) and in 20122015 (i. e. $\Delta \ln M_{95-07}^{\widehat{\mathrm{IAD}, \mathrm{d}} \mathrm{r}}$ ). In a similar way we get the import growth for the average economy

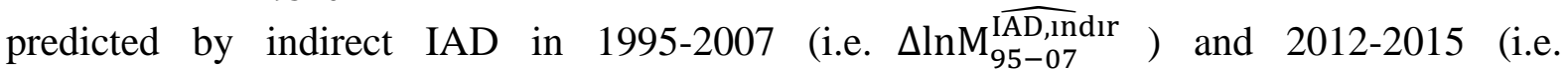

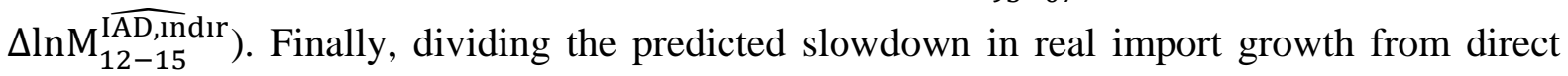
IAD by the actual slowdown in real import growth we get the contribution of direct IAD in the real import slowdown, $\gamma_{\mathrm{IAD}, \mathrm{dir}}$, for the average economy:

( 14) $\gamma_{\text {IAD,dir }}=\frac{\Delta \ln M_{12-15}^{\widehat{I A D, d i r}}-\Delta \ln M_{95-07}^{\widehat{I A D, d}}}{\Delta \ln M_{12-15}-\Delta \ln M_{95-07}}$

The percentage of import slowdown explained by the indirect IAD , $\gamma_{\text {IAD,indir }}$ is computed in a similar way:

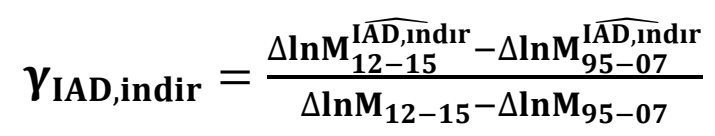

Source: Bussiere et al. (2013) 


\section{Box3: Global Value Chain participation index}

Individual economies participate in global value chains by importing foreign inputs to produce the goods and services they export (backward GVC participation) and also by exporting domestically produced inputs to partners in charge of downstream production stages (forward GVC participation). See Figure below.

Figure 1: Gross exports and GVC trade flows

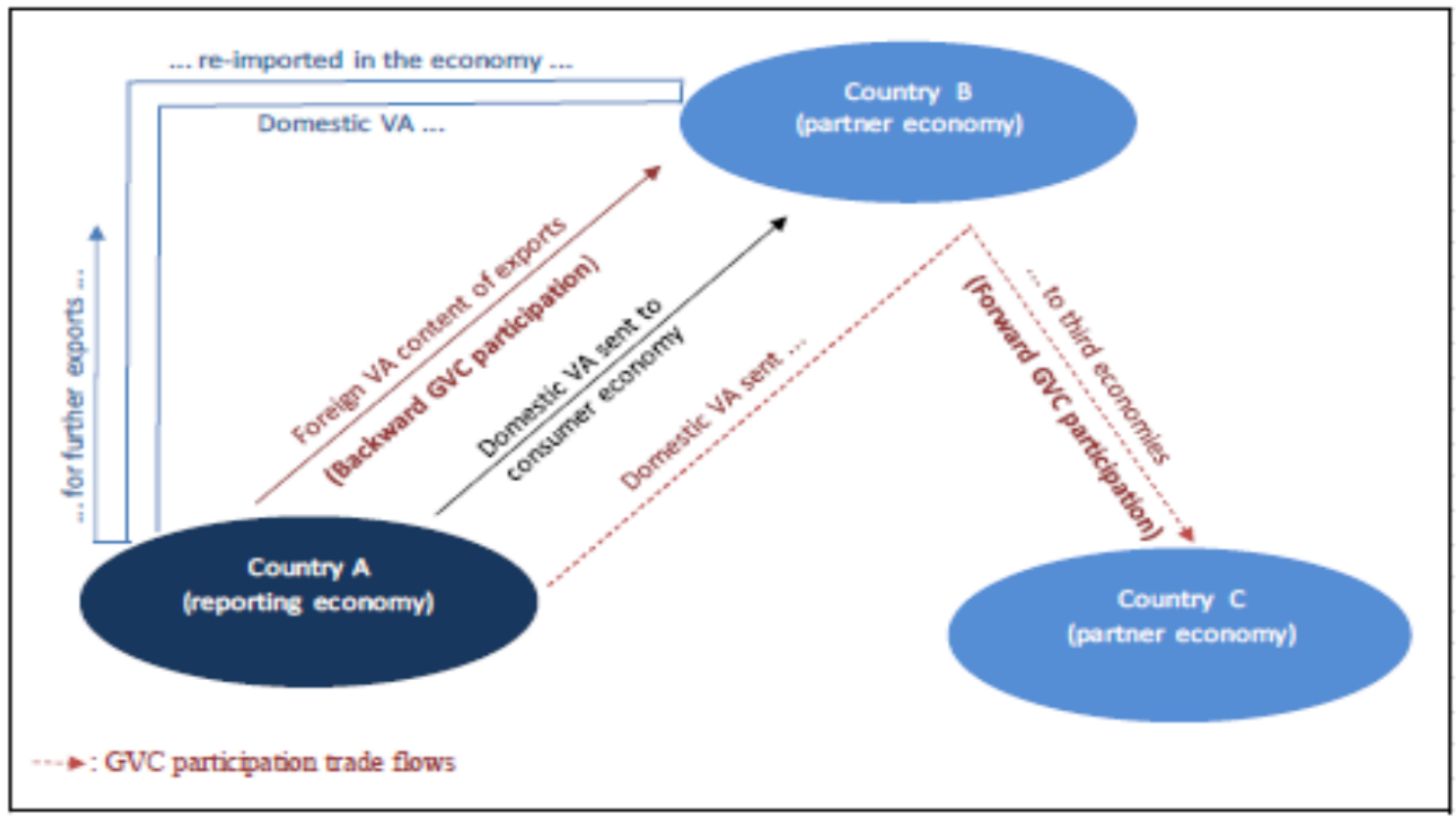

The GVC participation index of country c is given by the sum of backward (FV) and forward (IV) linkages of an economy c with its foreign partners, divided by its gross exports (E).

$$
G V C \text { partecipation index }=\frac{I V+F V}{E}
$$

Forward participation to GVCs (IV) captures the domestic value added contained in inputs sent to third economies for further processing and export through the value chain. This is the 'seller-related' measure or supply side in the GVC participation index.

Backward participation to GVCs (FV) refers to the value added of inputs that were imported in order to produce intermediate or final goods/services to be exported. This is the 'Buyer' perspective or sourcing side in GVCs, where an economy imports intermediates to produce exports. 
IAD

$$
1.503^{* * *}
$$

$$
0.0808 * * *
$$

Participation in GVC

Constant

$$
0.00981^{* * *}
$$

$$
\text { 2,859 }
$$$$
0.704
$$

Observations

$$
38
$$

Number of countries

Note: The table shows estimates of Equation 5, performed on the full set of 38 countries between 1995:I and 2015:IV (quarterly data). To save space we did not report the point estimates of the lagged value of the dependent variable and import demand. Import demand is measured as IAD using the average import intensity between 1995 and 2015 as weights. Robust standard errors in parentheses *** $\mathrm{p}<0.01, * * \mathrm{p}<0.05, * \mathrm{p}<0.1$ 
Box4: Calculating an alternative model of import demand for dealing with exports

We estimated an alternative model of import demand using domestic IAD and exports predicted by trading partners' domestic IAD.

Domestic IAD is defined as:

$$
\ln D I A D_{t}=\omega_{C, t}^{d} * \ln C_{t}+\omega_{G, t}^{d} * \ln G_{t}+\omega_{I, t}^{d} * \ln I_{t}
$$

Where the weights $\left(\omega_{k, t}^{d}\right.$, with $\left.k=C, G, I\right)$ are the total import content of each of the domestic demand expenditure components and are normalised in each year so that they sum up to 1 .

In order to compute the exports predicted by partners' DIAD, we followed the methodology of IMF (2016). First, we got for each country the real import growth predicted

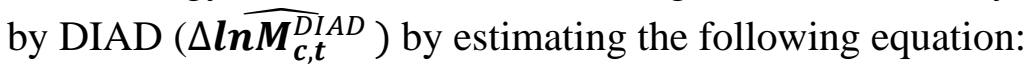

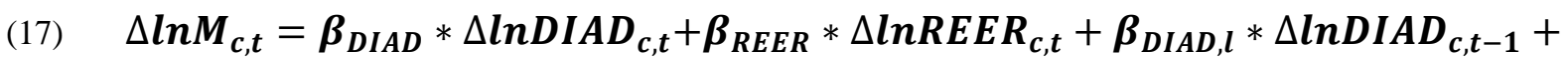
$\beta_{R E E R, l} * \Delta \ln R E E R_{c, t-1}+\beta_{M} * \Delta \ln M_{c, t-1}+\gamma_{c}+\varepsilon_{c, t}$

Second, since exports of a country are the sum of imports of its trading partners, we estimated a model where the export demand of a country is a function of trade weighted average of its five most important trading partners' real import growth predicted by DIAD.

$$
\Delta \ln X_{c, t}=\beta_{D} \sum_{j=1}^{5} \alpha_{c j} * \Delta \widehat{\ln M_{\jmath, t}^{D I} A D}+\gamma_{c}+\varepsilon_{c, t}
$$

Where $\boldsymbol{\alpha}_{\boldsymbol{c} \boldsymbol{j}}$ is the share of total exports of country c going to country $\mathrm{j}$ at time t. ${ }^{16}$ These export shares vary for each year and are reweighted to sum to 1 .

From the estimation of the equation above, we got the exports predicted by trading partners' DIAD $\left(\Delta \widehat{\boldsymbol{n} \boldsymbol{n} \boldsymbol{X}_{\boldsymbol{c}, \boldsymbol{t}}^{D I} A D}\right)$. Finally, we linked the real import growth of each country to the growth rate of its DIAD and its exports predicted by trading partners' DIAD, controlling for relative import prices:

(19) $\quad \Delta \ln M_{c, t}=\beta_{D I A D} \Delta \ln D I A D_{c, t}+\beta_{R E E R} \Delta \operatorname{lnREER} R_{c, t}+\beta_{X} \widehat{\ln X_{c, t}^{D I A D}}+$

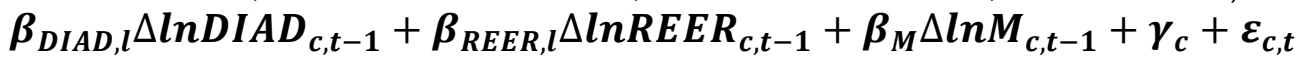

Source: IMF (2016)

\footnotetext{
${ }^{16}$ We consider only the top five export partners from World Integrated Trade Solution (WB).
} 
Box 5: Calculating the import content of aggregate demand components.

The National I-O tables (NIOT), from WIOD, illustrate flows between the sales and purchases, both final and intermediate, of industry output at country level. This is illustrated by the schematic outline for a NIOT involving only three industries in Figure 1. A useful feature of the NIOT is that intermediate inputs are divided into goods and services that are domestically-produced and those that are imported. Therefore, for each country, there are two main matrices: one focusing on domestically provided flows (domestic matrix, the green part in Figure 1) and the other focus on imported flows (import matrix, the yellow part in Figure 1). ${ }^{17}$ Each of these two matrices is divided into two parts: the first part describes the flows of intermediate inputs used in domestic production $(Z)$, the second describes the flows into final demand expenditures $(\mathrm{F})$.

Figure 1: Input-output table

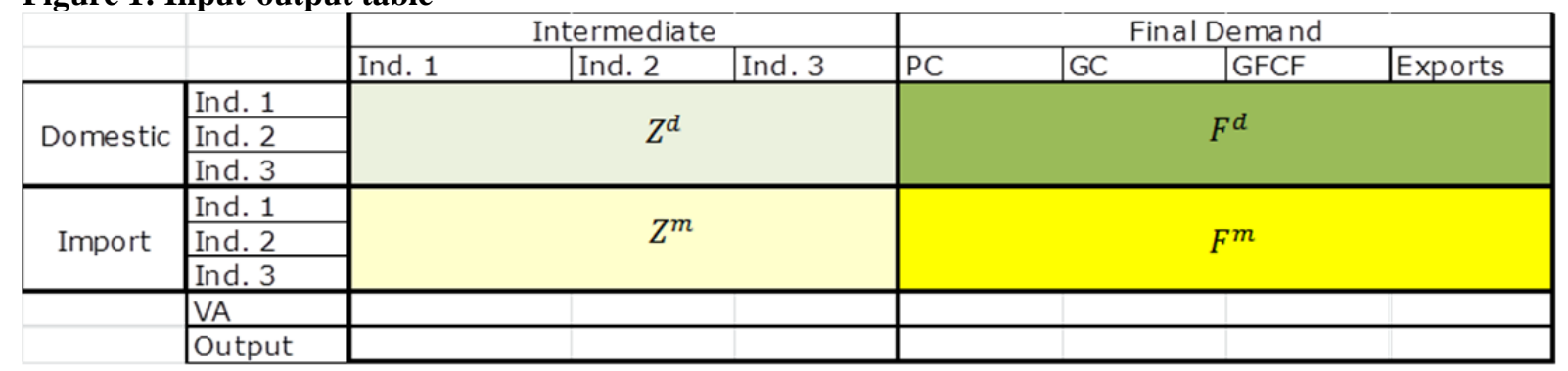

PC: private consumption, GC: government consumption, GFCF: Gross Fixed Capital Formation

VA: Value Added

In the part of the domestic matrix that describes flows of intermediate inputs $\left(Z^{d}\right)$, the cell $z_{i j}^{d}$ contains the value of domestically produced intermediate inputs from industry i (row) purchased by industry $\mathrm{j}$ (column) for domestic production throughout the year of reference. ${ }^{18}$ Similarly, the cell $z_{i j}^{m}$ of the import matrix contains the value of imported intermediate inputs from industry i (row) needed by industry j (column) for domestic production throughout the year of reference. Since the NIOT contains 35 sectors $Z^{d}$ and $Z^{m}$ are a $35 \times 35$ matrix.

As far as the matrix containing information on the final demand (F) is concerned, $f_{i k}^{d}$ reports the final demand of domestically produced goods and services from industry i by the final expenditure component $\mathrm{k}$ while $f_{i k}^{m}$ reports the direct import of goods and services from industry i needed by the final expenditure component k. Both $F^{d}$ and $F^{m}$ are 35x4 matrix. Let assume that output from each industry is used both as intermediate input by other industries and as final products by households and government (consumption) or firms (stocks and gross fixed capital formation). Using the domestic and import matrices, we can easily construct the value of direct and indirect imports and consequently the import content of each of the four expenditure components for each country and year.

\footnotetext{
${ }^{17}$ It does not indicate the country of origin of the imported intermediate inputs. This information is included in the inter-country matrix.

${ }^{18}$ Values in WIOT are in current prices, expressed in millions of US dollars and market exchange rates were used for currency conversion.
} 
The value of direct imports from each sector for each expenditure components $\left(M^{d i r}\right)$ can be computed directly from the import matrix:

$M^{\text {dir }}=F^{m}$

Note that the value of direct import of exports is assumed zero as re-exports are excluded from analysis. 19

The value of indirect imports ( $M^{\text {ind }}$ ) is the amount of imports induced by the expenditure on domestically produced goods and services. They include imports of intermediate goods and services from foreign suppliers or imports included in intermediate inputs acquired from domestic suppliers. In order to compute the indirect import, we need matrices $A^{d}$ and $A^{m}$ instead of $Z^{d}$ and $Z^{m}$. $A^{d}$ and $A^{m}$ are obtained simply dividing the value of each cell in $Z^{d}$ and $Z^{m}$ by the sum of the respective column (output in each sector). Then, the domestic input coefficient $a_{i j}^{d}$, in matrix $A^{d}$, contains the value of domestically produced intermediate inputs from sector i needed to produce one unit of domestic output in sector $\mathrm{j}$, and analogously, the import input coefficient $a_{i j}^{m}$ contains the value of imported intermediate inputs from sector i needed to produce one unit of domestic output in sector $\mathrm{j}$.

The imports of intermediate inputs from sector $\mathrm{i}$ induced by the expenditure on domestically provided goods and services for the expenditure component $\mathrm{k}, \mathrm{m}_{\mathrm{ik}}^{\mathrm{ind}}$, can be computed as follows:

In matrix form:

$$
m_{i k}^{i n d}=\sum_{j=1}^{35} a_{i j}^{m} * x_{j k}
$$

$M^{\text {ind }}=A^{m * \mathrm{X}}$

Where $\mathrm{x}_{\mathrm{ik}}$ is the domestic output from sector $\mathrm{i}$ needed to satisfy the final demand from expenditure component $\mathrm{k}$ and it is given by:

$x_{i k}=\sum_{j=1}^{35} a_{i j}^{d} * x_{i k}+f_{i k}^{d}$

In matrix form:

$$
X=A^{d} * X+F^{d}=>X=\left(I-A^{d}\right)^{-1} * F^{d}
$$

Therefore, substituting the matrix $\mathrm{X}$ of domestic output induced by each spending component $\mathrm{k}$ in the equation of the indirect import, we get:

$M^{\text {ind }}=A^{m *}\left(I-A^{d}\right)^{-1} * F^{d}$

It is important to highlight the difference between matrix $F^{d}$ and $\mathrm{X}$. The latter is a broader concept, it includes the final demand of domestically produced goods and services by each spending component $\mathrm{k}\left(F^{d}\right)$, as well as the value of domestically produced intermediate inputs needed to produce one unit of domestic output multiplied by the domestic output needed to satisfy the final demand from the expenditure $\mathrm{k}$.

\footnotetext{
${ }^{19}$ We are aware that for some countries, such as China, this assumption might be a bit problematic due to the high amount of processing trade.
} 
Once we have the direct and indirect imports, we can compute the direct and indirect import content of each expenditure component $\mathrm{k}$ as follows:

$$
\begin{aligned}
\omega_{k}^{\text {dir }} & =\frac{u * M^{d i r}}{u * F^{m}+u * F^{d}} \\
\omega_{k}^{i n d} & =\frac{u * M^{i n d}}{u * F^{m}+u * F^{d}}
\end{aligned}
$$

Where the first represents the share of imported final goods and services, and the second the share of intermediate imported inputs per unit of final demand.

The total import of each expenditure components is simply the sum of the direct and indirect imports:

$$
M=M^{d i r}+M^{\text {ind }}
$$

Therefore, the total import content of each expenditure component $\mathrm{k}$ is simply given by the sum of direct and indirect import content:

$$
\omega_{k}=\omega_{k}^{d i r}+\omega_{k}^{i n d}=\frac{u * M^{d i r}+u * M^{i n d}}{u * F^{m}+u * F^{d}}
$$

Source: Bussiere et al. (2013) 


\section{REFERENCES}

Alessandria, G., Kaboski, J.P. and Midrigan, V., 2010. The Great Trade Collapse of 2008-09: An Inventory Adjustment? IMF Economic Review, 58(2), 254-294.

Amiti, M. and Weinstein, D.E., 2011. Exports and Financial Shocks. Quarterly Journal of Economics. 126(4), 1841-1877.

Auboin, M. and Engemann, M., 2014. Testing the trade credit and trade link: evidence from data on export credit insurance. Review of World Economics, 150(4), 715-743.

Baldwin, R. E., ed. 2009. The Great Trade Collapse: Causes, Consequences and Prospects. London:Centre for Economic Policy Research. Available at: http://www.voxeu.org/epubs/cepr-reports/great-tradecollapse-causes-consequences-andprospects\#anchor.

Bems, R., Johnson, R. C., \& Yi, K. M. , 2013. The great trade collapse. Annual Review of Economics, 5(1), 375-400.

Bown, C. P., 2016. “Temporary Trade Barriers Database.” June. World Bank, Washington. Available at: http://econ.worldbank.org/ttbd/.

Bussière, M., Callegari, G., Ghironi, F., Sestieri, G. and Yamano, N., 2013. Estimating Trade Elasticities: Demand Composition and the Trade Collapse of 2008-2009. American Economic Journal: Macroeconomics, 5(3), 118-151.

Bussière M. and Ghironi F., Sestrieri G., 2012, Estimating trade elasticities: demand composition and the trade collapse of 2008-09, Vox column available at http://voxeu.org/article/understanding-great-trade-collapse-2009

Cheung, Y., M. D. Chinn, and X. Qian, 2012. Are Chinese Trade Flows Different? Journal of International Money and Finance, 31, 2127-46.

Chor, D. and Manova, K., 2012. Off the cliff and back? Credit conditions and international trade during the global financial crisis. Journal of international economics, 87(1), 117-133.

Christodoulopoulu, S. and Tkacevs, O., 2014. Measuring the effectiveness of cost and price competitiveness in external rebalancing of euro area countries: what do alternative HCIs tell us?, ECB Working Paper 17346.

Constantinescu, C., Mattoo, A. and Ruta, M., 2015. The Global Trade Slowdown: Cyclical or Structural? IMF Working Paper No. 15/6.

Devereux, M.B. and H. Genberg, 2007, "Currency Appreciation and Current Account Adjustment,” Journal of International Money and Finance, 26 ( 4), 570-86.

Di Giovanni, J. and Levchenko, A.A., 2010. Putting the parts together: trade, vertical linkages, and business cycle comovement. American Economic Journal: Macroeconomics, 2(2), 95-124. 
Eaton, J., Kortum, S., Neiman, B. and Romalis, J., 2016. Trade and the Global Recession. American Economic Review. 106(11), 3401-3438.

European Central Bank, 2016. Understanding the Weakness in Global Trade - What is the New Normal? ECB Occasional Paper No. 178. Available at SSRN: https://ssrn.com/abstract=2839779

Evenett, S.J., 2009. What can be learned from crisis-era protectionism? An initial assessment. Business and Politics, 11(3).

Evenett, S.J. and Fritz, J., 2015. The Tide Turns? Trade, Protectionism, and Slowing Global Growth - The 18th Global Trade Alert Report. CEPR Press.

Feenstra, R.C., 1994. New product varieties and the measurement of international prices. The American Economic Review, 157-177.

Freund, C.L., 2009. The trade response to global downturns: historical evidence. World Bank Policy Research Working Paper Series.

Giordano, C., \& Zollino, F., 2016. Shedding Light on Price and Non price competitiveness Determinants of Foreign Trade in the Four Largest euro area Countries. Review of International Economics, 24(3), 604-634.

Haugh, D., Kopoin, A., Rusticelli, E., Turner, D. and Dutu, R., 2016. Cardiac Arrest or Dizzy Spell: Why is World Trade So Weak and What can Policy Do About It? , OECD Economic Policy Papers, No.18, OECD Publishing, Paris. Available at: http://dx.doi.org/10.1787/5jlr2h45q532-en

Houthakker, H.S. and Magee, S.P., 1969. Income and price elasticities in world trade. The Review of Economics and Statistics, 111-125.

Krugman, P., 1989. Differences in income elasticities and trends in real exchange rates. European Economic Review, 33(5), 1031-1046.

International Monetary Fund. 2016. Global Trade: What's behind the Slowdown?, Chapter 2, in World Economic Outlook, Washington, October 2016.

Levchenko, A. A., Lewis, L. T., \& Tesar, L. L., 2010. The collapse of international trade during the 2008-09 crisis: in search of the smoking gun. IMF Economic review, 58(2), 214253.

Newey, W. K. and K.D. West, 1987. A Simple, Positive Semi-Definite, Heteroskedasticity and Autocorrelation Consistent Covariance Matrix,” Econometrica, 55(3), 703-708.

Yi, K.M., 2009. The collapse of global trade: the role of vertical specialization. The collapse of global trade, murky protectionism, and the crisis: Recommendations for the G20, 45-48. 
Wu, Y. (2005). Growth, Expansion of Markets, and Income Elasticities in World Trade. IMF Working Paper, 5011(200), 1-33. 